\title{
How climate change might affect tree regeneration following fire at northern latitudes: a review
}

\author{
Dominique Boucher $^{1}$ (D) . Sylvie Gauthier ${ }^{1,2}$ (D) . Nelson Thiffault ${ }^{3,4}$ (D) .

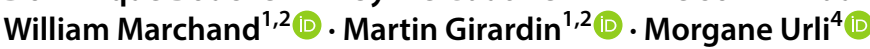

Received: 18 April 2019 / Accepted: 31 August 2019 / Published online: 20 September 2019

(C) The Author(s) 2019

\begin{abstract}
Climate change is projected to increase fire severity and frequency in the boreal forest, but it could also directly affect post-fire recruitment processes by impacting seed production, germination, and seedling growth and survival. We reviewed current knowledge regarding the effects of high temperatures and water deficits on post-fire recruitment processes of four major tree species (Picea mariana, Pinus banksiana, Populus tremuloides and Betula papyrifera) in order to anticipate the effects of climate change on forest recovery following fire in the boreal biome. We also produced maps of future vulnerability of post-fire recruitment by combining tree distributions in Canada with projections of temperature, moisture index and fire regime for the 2041-2070 and 2071-2100 periods. Although our review reveals that information is lacking for some regeneration stages, it highlights the response variability to climate conditions between species. The recruitment process of black spruce is likely to be the most affected by rising temperatures and water deficits, but more tolerant species are also at risk of being impacted by projected climate conditions. Our maps suggest that in eastern Canada, tree species will be vulnerable mainly to projected increases in temperature, while forests will be affected mostly by droughts in western Canada. Coniferdominated forests are at risk of becoming less productive than they currently are, and eventually, timber supplies from deciduous species-dominated forests could also decrease. Our vulnerability maps are useful for prioritizing areas where regeneration monitoring efforts and adaptive measures could be developed.
\end{abstract}

Keywords Drought $\cdot$ Temperature $\cdot$ Post-fire regeneration $\cdot$ Black spruce $\cdot$ Jack pine . Trembling aspen $\cdot$ Paper birch

Electronic supplementary material The online version of this article (https://doi.org/10.1007/s 1105 6-019-09745-6) contains supplementary material, which is available to authorized users.

Dominique Boucher

dominique.boucher@canada.ca

Extended author information available on the last page of the article 


\section{Introduction}

Wildfires are recurring, stand-replacing disturbances that affect forest dynamics and shape landscape diversity throughout the North American boreal biome (e.g., Van Wagner 1978; DeLong and Tanner 1996). As a consequence, most boreal tree species exhibit strong adaptive traits allowing for their rapid recovery after a fire (Shinneman et al. 2013), such as serotinous cones that occur in pines and spruces (He et al. 2012; Briand et al. 2015), or vegetative reproduction that occurs in aspen (Populus tremuloides Michaux). Fire can be beneficial to nutrient availability and site productivity, given that it releases nutrients that would otherwise be tied up in the humus, creates germination seedbeds, and reduces competing vegetation cover (Greene et al. 1999; Prescott et al. 2000; Miyanishi and Johnson 2002). However, fires can lead to a conversion of close stands into open forests (Payette and Delwaide 2018; Girard et al. 2009) or to a shift in forest composition (Johnson et al. 2003; Johnstone and Chapin 2006b; Beck et al. 2011) if they occur before trees have produced sufficient viable seed to ensure regeneration.

Temperature and drought frequency also affect post-fire recruitment processes through their effects on seed production, seed germination, and seedling growth and survival (Boiffin and Munson 2013). The climatic niches of seedlings are narrower than those of conspecific adult trees (Grubb 1977; Hogg and Schwarz 1997; Jackson et al. 2009; Lenoir et al. 2009; Bell et al. 2014; Dobrowski et al. 2015), making seedlings particularly vulnerable to drought (e.g., see Hogg and Schwarz 1997). Therefore, regeneration failures are possible, even under climate conditions that are suitable for mature individuals (Dodson and Root 2013). Furthermore, microclimatic conditions of burned areas are usually more extreme than those of the surrounding forested matrix (Ulery and Graham 1993; Feddema et al. 2013; Savage et al. 2013). They typically exhibit higher local temperatures owing to the increase in solar radiation that reaches the forest floor, the loss of insulating effects provided by the organic layer (Bonan 1989; Feddema et al. 2013; Savage et al. 2013), and the dark colour of burned soils (Ulery and Graham 1993).

Changes in post-fire regeneration have been observed in recent decades in many parts of the world and have been attributed mainly to ongoing climate change (Donato et al. 2016; Rother and Veblen 2016; Stevens-Rumann et al. 2017). For instance, in Alaska and central Canada, more deciduous species are now observed in the regeneration layer after fire rather than conifer species such as black spruce (Picea mariana (Mill.) BSP), apparently due to warmer and drier climate conditions (Bond-Lamberty et al. 2007; Kasischke et al. 2007; Johnstone et al. 2010a, b; Beck et al. 2011; Walker et al. 2017). In the Yukon (Canada), warm south-facing slopes support fewer white spruce (Picea glauca [Moench] Voss) and more aspen seedlings after fire than have been observed historically (Johnstone et al. 2010b), suggesting an eventual shift in forest composition. In eastern Canada, little evidence of changes in post-fire recruitment has been observed so far, but Van Bogaert et al. (2015) concluded that jack pine (Pinus banksiana Lambert) can often be replaced by black spruce following fire on dry sites; these authors also reported greater regeneration failure of jack pine than expected, suggesting that the species is less resilient to fire on dry sites. Such empirical demonstrations of post-fire recovery changes are still scarce, and their underlying processes are not well understood. It is anticipated, however, that fire severity and frequency within the North American boreal biome will increase over the next century under continued warming (Rogers et al. 2011; Flannigan et al. 2013; Barbero et al. 2015; Terrier et al. 2015). Given that regeneration success requires suitable pre-fire seed production and adequate post-fire climatic conditions (Hogg and Wein 2005; Dodson and Root 
2013; Harvey et al. 2016), the microclimatic conditions of burned areas, in combination with the potential effects of projected climate change, could impair the establishment of some tree species. Such changes need to be anticipated so that adequate adaptive measures can be developed and established in order to attenuate or offset potential negative impacts of climate change, and to support long-term fibre supplies.

In this paper, we first reviewed the literature on the effects of high temperature and water deficits on post-fire recruitment processes, i.e., seed production, seed germination, vegetative reproduction, and seedling growth and survival in North American boreal forests. By focusing on these effects, we wanted to assess whether the expected decrease in the closed-canopy boreal forest that would be due to an increase in fire frequency could be exacerbated in the future (Tepley et al. 2017; Serra-Diaz et al. 2018; Stevens-Rumann et al. 2017). This review also allowed us to highlight research gaps that should be filled to extend our understanding of post-fire recruitment dynamics under a changing climate. We focused on four major boreal tree species found in North American forests, i.e., black spruce, jack pine, trembling aspen, and paper birch (Betula papyrifera Marshall). Together, these species of high commercial value are dominant in some 268 million hectares of forest land in boreal Canada (Brandt 2009). In addition, as a complement to the literature review, we produced maps of the future vulnerability of post-fire recruitment of the four tree species, by combining their distributions in Canada with projected changes in temperature, moisture index and fire regime. These maps will help to spatially anticipate the most probable impacts of climate change on post-fire recruitment for each species.

\section{Methods}

\section{Literature review}

We conducted a literature search, initially by focusing on publications reporting the first evidence of climate change impacts on post-fire recruitment. Given the scarcity of these studies, we extended the search to studies on effects of climate conditions on postfire recruitment. We focused on low water availability and high temperature conditions, based on projected climate conditions. We then extended the search to studies on relationships between recruitment processes and climate variables, specifically water availability and temperature, in contexts other than post-fire conditions. This last category of studies mostly included experiments conducted in controlled environments, with few studies under natural conditions. We limited our search to the main North American boreal species: black spruce, jack pine, paper birch, and trembling aspen. We selected publications that discussed at least one of the recruitment stages: seed production and germination, seedling growth and survival, and vegetative reproduction. In addition, we included studies conducted in natural conditions reporting seedling density after fires. We chose not to address indirect effects of climate change on regeneration, such as the impacts of increased fire severity and frequency on post-fire recruitment. Specifically, the literature search was conducted in the Scopus database (https://www.scopus.com/) for each of the four species, using the following keywords: "climate change" or "climate warming" or "global change" or "global warming" and "boreal forest" and "fire" and "recruitment" or "seed" or "seedling" or "sapling" or "regeneration" or "germination" or "sucker" or "vegetative reproduction" or "recovery". To search for studies on the effects of climate conditions rather than climate change, we used "drought" or "temperature" or "precipitation" or "water deficit" or 
"growth season" instead of the climate change keywords. We removed "fire" as a keyword to search for studies on recruitment processes in contexts other than post-fire conditions. We also included relevant articles found as citations in the searched articles. Overall, we identified 34 relevant publications regarding the effects of temperature and 21 publications regarding the effects of water availability on recruitment processes. For each recruitment stage, tree responses to climate change or climate conditions observed in each study were compiled (Table S1 and S2) and synthesized, allowing for the characterization of potential species sensitivity to temperature increase and drought.

\section{Maps of tree species vulnerability to climate change}

To add a spatial dimension to the anticipated impacts of climate change on post-fire recruitment, and to complement the information found in our review, we produced maps of the vulnerability of tree species to changing conditions. In fact, the impacts of climate change on post-fire recruitment will depend not only on species sensitivity, as covered in the literature review, but also on their exposure to change. Specifically, impacts will depend on location within the species' range (Reich et al. 2015; Chaste et al. 2019) and on the limiting factors of the local conditions (Boisvenue and Running 2006; Terrier et al. 2015; Pedlar and McKenney 2017). Furthermore, temperature, drought frequency and fire frequency projections for the end of the century are spatially heterogeneous throughout Canada, even within a given climatic scenario (Fig. 1). Hence, the vulnerability of post-fire recruitment for a given species should be the highest in locations where the greatest climatic change coincides with the distribution of the species. By overlaying information on climatic envelopes of tree species with climate and fire projections, we can illustrate where the projected climate variables are likely to exceed the climate envelope of a tree species at the pixel level $(250 \times 250 \mathrm{~m})$.

Species climatic envelopes are useful for illustrating species vulnerability to climatic change (Heikkinen et al. 2006; McKenney et al. 2007; Bell et al. 2014). If the value of a projected climatic variable at a given location exceeds the climatic envelope of a species, it can be assumed that this species will be vulnerable to the new climatic conditions at this location. Climatic envelopes have been calculated for mature trees and are probably larger than those of seedlings or saplings (Grubb 1977; Hogg and Schwarz 1997; Jackson et al. 2009; Lenoir et al. 2009; Bell et al. 2014; Dobrowski et al. 2015), but they constitute the best available information to approximate zones of vulnerability for post-fire tree recruitment. We used mean annual temperature and Climate Moisture Index (CMI) projections that were based on the CanESM2 RCP 8.5 model for 2041-2070 and 2071-2100, provided by the BioSIM v11.5.5.1 software tool for Canada's entire boreal region (Régnière and St-Amant 2007). The RCP (Representative Concentration Pathway) 8.5 model represents an extreme but realistic situation, characterized by increasing greenhouse gas emissions over time. To produce the maps, we used tree species envelopes produced by McKenney et al. (2007, 2013) for Canada (Table 1), as well as tree species biomass maps created by Beaudoin et al. (2018) with a resolution of $250 \mathrm{~m} \times 250 \mathrm{~m}$. For each pixel, a species was classified as vulnerable when its biomass represented at least $10 \%$ of the pixel, and if the projected annual temperature within the pixel was higher than the 95th percentile of its temperature envelope, or if the projected CMI was lower than the 5th percentile of its hydric envelope. Since we aimed to illustrate the vulnerability of species recruitment under post-fire conditions, we also based our maps on fire projections drawn from the same RCP produced by Boulanger 

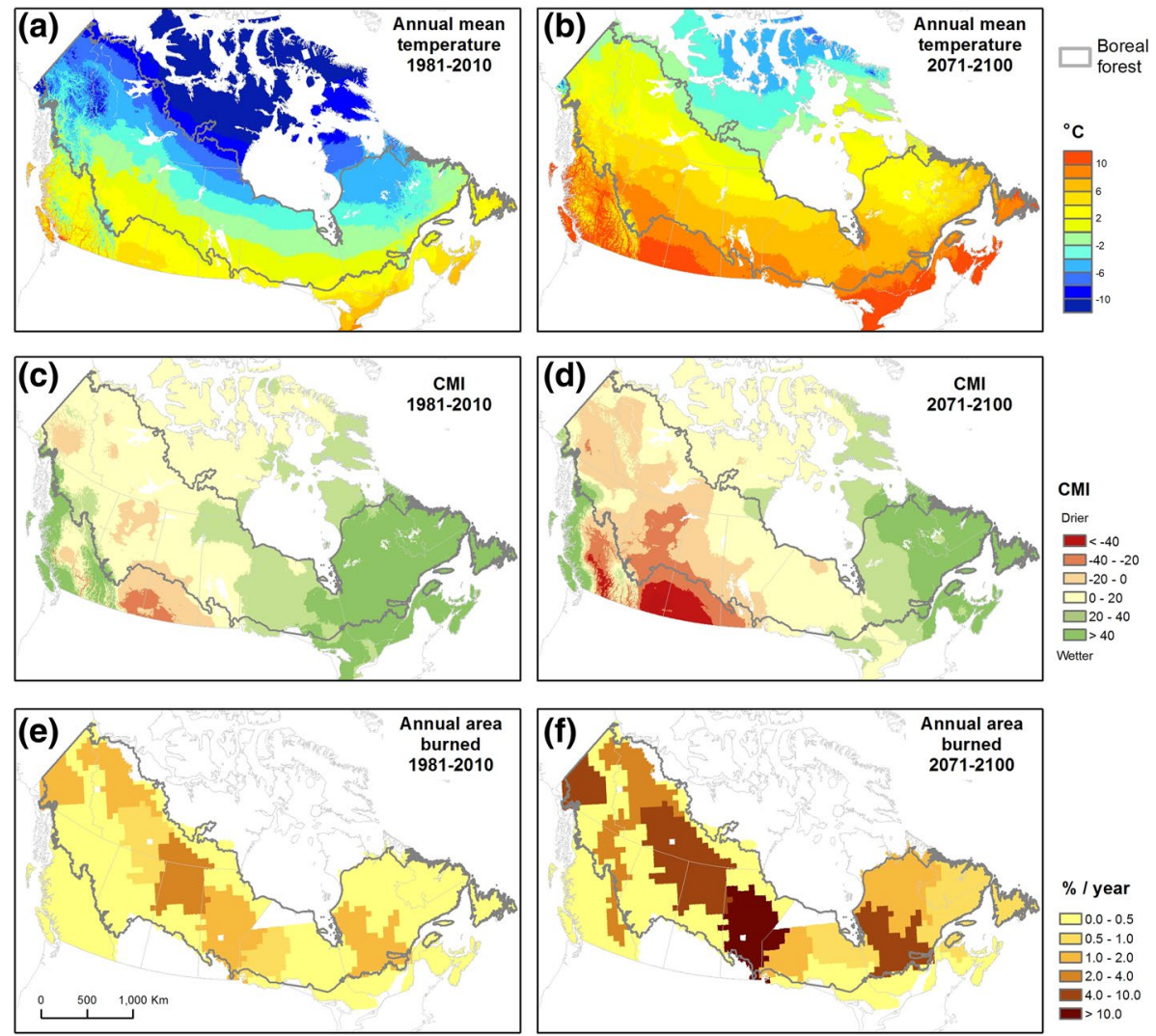

Fig. 1 Projections of annual mean temperature $\left({ }^{\circ} \mathrm{C}\right)$, Climate Moisture Index (CMI) and annual burned area (\%/yr) for the 1981-2010 and 2071-2100 periods based on the CanESM2 RCP 8.5 model

Table 1 Climatic envelopes of mature black spruce, jack pine, trembling aspen and paper birch produced by McKenney et al. $(2007,2013)$

\begin{tabular}{llllllll}
\hline & \multicolumn{3}{l}{ Mean annual temperature } & & \multicolumn{3}{l}{ Climate moisture index } \\
\cline { 2 - 3 } & Mean & 5th perc. & 95th perc. & & Mean & 5th perc. & 95th perc. \\
\hline Black spruce & 0.93 & -3.34 & 5.58 & & 32.46 & -2.06 & 88.55 \\
Jack pine & 1.07 & -2.55 & 5.81 & & 25.03 & -2.76 & 66.52 \\
Trembling apsen & 2.41 & -2.36 & 7.37 & & 23.20 & -9.96 & 68.30 \\
Paper birch & 3.91 & -0.36 & 7.50 & & 31.35 & 0.45 & 69.94 \\
\hline
\end{tabular}

Italicized values used to produce the maps of vulnerability to climate change

et al. (2014) for 2041-2070 and 2071-2100. We considered that annual burned areas of $0.5-1 \%, 1-4 \%$, and $>4 \%$ represent medium, high and very high risks, respectively. Thus, the post-fire recruitment of a species was considered to be more vulnerable to drought or temperature where the projected annual burned area was high. 


\section{Literature review: effects of climate on tree recruitment}

Temperature and water availability both play important roles in all stages of tree development and reproduction, from seed production to seedling growth and survival, including vegetative reproduction. Depending on the species, certain developmental stages are more vulnerable to variation in these climate variables than are other stages (Ibáñez et al. 2017). In this section, we review the effects of temperature and water availability on sexual and vegetative stages of regeneration: (1) seed production and availability; (2) seed germination; (3) vegetative reproduction; and (4) seedling and sucker growth and survival. The list of relevant articles that discuss how water deficit and temperature affect tree recruitment is presented in Tables S1 and S2, respectively.

\section{Seed production and availability}

\section{Temperature}

The role of temperature in the production of viable seeds has been documented for many forest ecosystems (Henttonen et al. 1986; Zasada et al. 1992; Parantainen and Pulkkinen 2002; Roland et al. 2014; Nussbaumer et al. 2018). Low temperatures are usually a factor limiting seed production (including bud differentiation, flowering, pollination, and seed maturation) at the northern limit of a tree's range (Pigott and Huntley 1981; Morin et al. 2007). Seed production is generally closely related to inter-annual variation in climatic conditions (Henttonen et al. 1986; Woodward et al. 1994; Koenig and Knops 1998; Drobyshev et al. 2010; Zamorano et al. 2018), warmer and longer growing seasons allowing a greater amount of carbon uptake, and greater carbon allocation to reproduction (Despland and Houle 1997; Lucas-Borja and Vacchiano 2018; Zamorano et al. 2018). However, both cold and hot extremes can be significant causes of early fruit and flower mortality (Krugman et al. 1974; Rodrigo 2000; Vitasse et al. 2018), thereby decreasing the number of viable seeds.

For jack pine trees growing at the northern limit of their distribution range, higher than average temperatures during the three growing seasons required for seed production increase the production of viable seeds (Despland and Houle 1997). Similarly, paper birch produced more seeds on warmer sites in Appalachian forests (Grenier and Sirois 2009). Black spruce cone production does not increase with degree-days or maximum summer temperature in boreal Québec, Canada (Sirois 2000; Messaoud et al. 2007), but the number of filled seeds (with embryo development) per cone is positively correlated with the cumulative number of degree-days (Sirois 2000). At the northern tree line, the seed production of most species, including black spruce, is greatest when high degree-day sums coincide with years in which high precipitation is recorded (Brown et al. 2019).

\section{Water availability}

Seed production is linked to precipitation and can be reduced by drought (Allen et al. 2014; Roland et al. 2014; O'Brien et al. 2018; Brown et al. 2019). In boreal forests, desiccation has been implicated as one of the key factors involved in seed mortality that occurs during the first summer following fire (Greene et al. 1999), especially in regions where droughts are infrequent (Tweddle et al. 2003). Larger seeds, such as those found in conifers, 
generally have higher survival rates than smaller seeds (Greene et al 1999). However, there have been few studies that examine the impact of water deficit on seed production specifically for black spruce, jack pine, trembling aspen, and paper birch.

\section{Seed germination}

\section{Temperature}

Temperature is a key factor for seed germination in many boreal tree species (Zasada et al. 1992). Germination generally starts in the spring, when temperatures reach a specific threshold. For example, black spruce seeds germinate at temperatures $>15{ }^{\circ} \mathrm{C}$ (Black and Bliss 1980), or when the cumulative heat sum reaches from 800 to 940 degree-days (Meunier et al. 2007). Germination success increases with both temperature and degree-days for black spruce (Hobbie and Chapin 1998; Sirois 2000; Munier et al. 2010), paper birch (Hobbie and Chapin 1998; Grenier and Sirois 2009), and trembling aspen (Zasada and Viereck 1975; Hobbie and Chapin 1998), up to a maximum threshold. However, Grenier and Sirois (2009) found higher paper birch germination success on colder sites in Appalachian forests. No black spruce germination was observed beyond $35{ }^{\circ} \mathrm{C}$ (Fraser 1970a). Likewise, optimal temperatures for trembling aspen germination in growth chambers range from 20 to $32{ }^{\circ} \mathrm{C}$; while the rate decreases with temperatures above $30{ }^{\circ} \mathrm{C}$, no germination is observed at $40{ }^{\circ} \mathrm{C}$ (Faust 1936; McDonough 1979; Fechner et al. 1981). Jack pine seed germination can occur optimally from 15 to $32{ }^{\circ} \mathrm{C}$ (Fraser 1970b). Unlike the previous two species, jack pine seeds can germinate at $40{ }^{\circ} \mathrm{C}$, but with limited success (20\%; Ackerman and Farrar 1965; Fraser 1970b). Jack pine germination also is faster when exposed to $30{ }^{\circ} \mathrm{C} / 20{ }^{\circ} \mathrm{C}$ (day/night) compared to $20{ }^{\circ} \mathrm{C} / 10{ }^{\circ} \mathrm{C}$ regimes (Greenwood et al. 2002). Furthermore, seeds from northerly populations of jack pine and paper birch germinated faster than those from southerly populations (Bevington 1986; Benowicz et al. 2001; Greenwood et al. 2002). Indeed, northern provenances of paper birch germinate more rapidly and in higher proportions between 21 and $34{ }^{\circ} \mathrm{C}$, whereas this optimum range is $27-34{ }^{\circ} \mathrm{C}$ for southern sources (Bevington 1986). Rapid germination represents an advantageous trait for populations whose growing season duration is limited (Benowicz et al. 2001).

\section{Water availability}

Water availability is crucial for boreal species germination. For example, no emergence of jack pine was observed at a moisture level equivalent to $50 \%$ of the average daily June rainfall in Ontario, Canada (Herr and Duchesne 1995). The ability of seeds to germinate under moisture deficit conditions differs between species. Sirois (1993) found a higher germination rate for jack pine, compared to black spruce, on dry substrates following fire in northern Québec, Canada. Thomas and Wein (1985) found similar germination rates between jack pine and black spruce under water-deficit conditions, but observed a higher emergence of jack pine on soils that were watered at different frequencies. They explained these results as greater survival in pre-emergent jack pine seedlings, due to their faster radicle elongation. The germination rate of trembling aspen seeds on a substrate where the water potential was - 0.4 MPa was only 50\% (McDonough 1979), while no germination was observed at water potential of $-0.7 \mathrm{MPa}$ (McDonough 1979; Fechner et al. 1981).

Furthermore, many authors have observed that few seedlings establish on thick residual organic matter after fire (Chrosciewicz 1974; Charron and Greene 2002; Johnstone and 
Chapin 2006a; Hesketh et al. 2009; Boiffin and Munson 2013). The substrate resulting from the incomplete combustion of the organic layer typically exhibits low water retention and high variation in temperature (Duchesne and Sirois 1995; Miyanishi and Johnson 2002; Johnstone and Chapin 2006a), particularly when warm and dry summers follow the fire (Boiffin and Munson 2013). Under these conditions, Boiffin and Munson (2013) observed greater establishment success for jack pine seedlings compared to black spruce in eastern Canada.

\section{Vegetative reproduction}

Vegetative reproduction circumvents detrimental post-fire conditions, such as extreme temperatures and drought events, by enabling rapid regeneration after fire. While post-fire recruitment through vegetative reproduction is common for trembling aspen, this post-fire regeneration strategy is much less common for paper birch, and is absent in black spruce and jack pine (Foster and King 1986; Perala and Alm 1990; Safford et al. 1990; Zasada et al. 1992).

\section{Temperature}

Warm soils favour sucker initiation by facilitating auxin degradation, and by promoting root growth and cytokinin synthesis (Schier et al. 1985; Hungerford 1988; Bradley et al. 1992). A soil temperature of $8{ }^{\circ} \mathrm{C}$ inhibits the expansion of trembling aspen root suckers (Landhäusser et al. 2006), likely because cold temperatures limit moisture uptake (Wan et al. 1999). Silvicultural practices such as scarification favour aspen suckering because the treatment affects the soil temperature (Lavertu et al. 1994; Paragi and Haggstrom 2007). High temperatures can improve sucker establishment by stimulating early sucker initiation, with positive effects on sucker growth and survival (Fraser et al. 2002; Frey et al. 2003; Landhäusser et al. 2006). Both the number and growth of aspen suckers are optimal between 23 and $30{ }^{\circ} \mathrm{C}$, but they decline at higher temperatures (Maini and Horton 1964, 1966; Zasada and Schier 1973).

\section{Water availability}

Some studies have suggested that the production of aspen suckers after fire could be affected by drought episodes. In the Yukon, Hogg and Wein (2005) observed that most aspens regenerated after a 1958 fire that originated during a drought-free period, while few aspens were produced during the following severe drought episodes. Very dry soils reduce aspen sucker initiation on root cuttings (Schier et al. 1985), although maximal sucker production was observed at $7 \%$ soil moisture content, in an experiment covering a 7-27\% gradient (Maini and Horton 1964). Evidence for the detrimental effects of drought on sucker production is not clear. It appears that the sucker initiation process in aspen can occur under moderate water deficits, probably due to the deep root system that draws upon untapped soil moisture reserves, thereby avoiding surficial soil desiccation (Harvey et al. 2016).

We found no studies that investigated the effect of temperature or drought on paper birch resprouting. 


\section{Seedling and sucker growth and survival}

\section{Temperature}

In cold regions, temperature is recognized as the factor that is most limiting to growth (Bonan 1992; Körner 2003; Rossi et al. 2008), and moderate warming generally leads to greater seedling growth and survival, mainly through direct effects on photosynthesis and thus on assimilation rates (Dang and Cheng 2004; Wilmking et al. 2004; Danby and Hik 2007; Pallardy 2008). Temperature also affects indirectly growth through nutrient and water uptake, due to increased metabolism and evapotranspiration under warmer conditions (Bonan 1992). Projected global warming may increase the length of the growing season in cold regions, which in turn may benefit seedling growth (Myneni et al. 1997; Rossi et al. 2011). Furthermore, high soil temperatures following fire result in increased organic matter decomposition and nutrient mineralization, with potential positive effects on postfire seedling growth (Dyrness and Norum 1983; Viereck 1983). Yet the beneficial effects of such climate warming on boreal tree growth may be short-lived, given concomitant declines in soil moisture storage and availability (D'Orangeville et al. 2018). On one hand, high temperature can induce summer water stress that attenuates or precludes temperaturerelated growth increases (Briffa et al. 1998; Barber et al. 2000; Lloyd and Fastie 2002; Wilmking et al. 2004; Ols et al. 2016). On the other hand, an increase in winter temperatures could have differing effects from those of summer-time increases (Cannell and Smith 1986; Vitasse et al. 2018). For example, at elevational tree line in Québec, higher winter temperatures and a shortened snow cover duration resulted in decreased seedling survival through early dormancy release, which exposed seedlings to freezing temperatures (Renard et al. 2016).

Black spruce Growth chamber studies have shown strong interspecific variability in tree seedling responses to temperature variation. Black spruce seedling growth takes advantage of moderate increases in temperature $\left(3-15^{\circ} \mathrm{C}\right)$, but to a lesser extent than do seedlings of deciduous species, (Landhäusser et al. 1996; Peng and Dang 2003; Dang and Cheng 2004). Optimal temperatures for black spruce seedling growth in the laboratory range between 16 and $21{ }^{\circ} \mathrm{C}$ (Tjoelker et al. 1998; Peng and Dang 2003; Dang and Cheng 2004; Zhang and Dang 2007; Way and Sage 2008), although good growth has been observed at $27{ }^{\circ} \mathrm{C}$ (Zhang and Dang 2007); above these thresholds, decreases in seedling growth are most likely due to the decrease in carbon allocation to the roots at high temperatures (Way and Sage 2008). Only $20 \%$ of black spruce seedlings growing at $35^{\circ} \mathrm{C}$ over a period of 4 months survived (Peng and Dang 2003; Dang and Cheng 2004). The mortality of black spruce seedlings has been found to be higher on southern rather than northern slope aspects in Alaska, particularly during periods where average daily maximum soil temperatures are above $29{ }^{\circ} \mathrm{C}$ (Viereck and Dyrness 1979).

Jack pine Jack pine seedlings are less responsive to variation in temperature than are black spruce seedlings (Peng and Dang 2003; Dang and Cheng 2004; Zhang and Dang 2007). Moderate temperature increases favour jack pine seedlings, but higher temperatures cause decreased growth (Heninger and White 1974; Peng and Dang 2003; Dang and Cheng 2004; Zhang and Dang 2007; Reich et al. 2015). After 4 months at $35^{\circ} \mathrm{C}$ in growth chambers, only $40 \%$ of seedlings survived (Peng and Dang 2003; Dang and Cheng 2004). Both a warming of $3.4{ }^{\circ} \mathrm{C}$ in Minnesota (Reich et al. 2015) and $4-5{ }^{\circ} \mathrm{C}$ above the ambient nighttime tem- 
perature in a growth chamber (Day et al. 2005) reduced jack pine seedling growth. Thus, an optimal growth temperature for jack pine would be between 22 and $27{ }^{\circ} \mathrm{C}$ (Heninger and White 1974; Peng and Dang 2003; Dang and Cheng 2004).

Trembling aspen Growth rates of trembling aspen seedlings and suckers are reduced by low soil temperatures (Landhäusser and Lieffers 1998), and are strongly increased with moderate increases in temperature $\left(6-20^{\circ} \mathrm{C}\right)$. Growth chamber studies suggest that the optimal growth temperatures for trembling aspen seedlings and suckers are between 19 and $23{ }^{\circ} \mathrm{C}$ (Maini and Horton 1964, 1966; McDonough 1979; Peng and Dang 2003; Dang and Cheng 2004). Seedlings can attain seven times their minimal biomass value at their optimal temperature (Peng and Dang 2003; Dang and Cheng 2004). At a high temperature $\left(35^{\circ} \mathrm{C}\right)$, trembling aspen seedlings showed no mortality after 4 months (Peng and Dang 2003; Dang and Cheng 2004). Warming of $3.4{ }^{\circ} \mathrm{C}$ in Minnesota led to a slight increase in trembling aspen seedling growth (Reich et al. 2015), while no significant increase was observed following 3 years of warming of $1{ }^{\circ} \mathrm{C}$ in Alaska (Hobbie and Chapin 1998).

Paper birch Optimal growth temperatures for paper birch seedlings are estimated to be between 17 and $31^{\circ} \mathrm{C}$ (Heninger and White 1974; Zhang and Dang 2007). A warming of $3.4{ }^{\circ} \mathrm{C}$ in Minnesota resulted in decreased paper birch seedling growth (Reich et al. 2015), while a warming of $1{ }^{\circ} \mathrm{C}$ in Alaska did not affect growth after 3 years (Hobbie and Chapin 1998). High seedling mortality was observed on southern slope aspects in Alaska, where the temperature was often above $29^{\circ} \mathrm{C}$; mortality rates are higher for paper birch than for black spruce (Viereck and Dyrness 1979). Paper birch seedlings from high elevation populations in New Hampshire showed a decrease in growth rate when they were grown at low elevations in warmer temperatures (Ruel and Ayres 1996).

\section{Water availability}

Moderate water deficiency could affect seedling growth directly through the effects on cambial cells, or indirectly through effects on photosynthesis (Abe and Nakai 1999; Arend and Fromm 2007; Rossi et al. 2009; de Luis et al. 2011), while severe drought can cause tree mortality through hydraulic failure or carbon starvation (Sala et al. 2012; Nardini et al. 2013; Urli et al. 2013; Anderegg et al. 2012, 2016). Tree species possess different strategies to cope with water stress [mainly dehydration avoidance and dehydration tolerance according to Volaire's definition (2018)] and show different performances under drought stress.

Black spruce Black spruce shows anisohydric behaviour by keeping the stomata open and maintains high photosynthetic rates for a long period during water stress (dehydration tolerance), but its risk of hydraulic failure is higher than for isohydric species, especially during intense drought (McDowell et al. 2008; Choat et al. 2012; Sade et al. 2012; Pappas et al. 2018). Black spruce has a higher resistance to embolism than the other boreal species that are covered here, though its low degree of stomatal control increases the probability of embolism (Hacke and Jansen 2009; Choat et al. 2012). Hébert et al. (2006) found lower growth rates for planted black spruce seedlings, compared to jack pine, under dry conditions in boreal lichen woodlands in Québec, although survival was similar between species. Sirois (1993) found greater mortality at 13 months for black 
spruce seedlings compared to jack pine on dry substrates following fire in northern Québec. Blake and Li (2003) attributed the lower water stress resistance of black spruce, in comparison with jack pine, to a greater needle area and smaller root system. Black spruce seedlings growing at high temperatures have been found to decrease their biomass allocation to roots, thereby making them more susceptible to episodic soil drying (Way and Sage 2008). Black spruce seedling mortality is generally high during the first year following fire (Black and Bliss 1980), mainly due to seedbed drying (Charron and Greene 2002; Moss and Hermanutz 2009). Mortality also occurs among older seedlings. In a 1-month-long water-stress treatment experiment, Balducci et al. (2013) observed an increase in 4-year-old black spruce seedling mortality, the effect of which was stronger at higher temperatures. Kasischke et al. (2007) found that black spruce recruitment can be dramatically lowered in dry post-fire conditions in Alaska, while Johnstone et al. (2010a) observed black spruce self-replacement primarily on moist sites that burn with low-severity fire.

Jack pine Jack pine resistance to and survival of water stress is reflected by its occurrence on dry soil deposits (Blake and Li 2003). This species exhibits relatively isohydric behaviour that is characterized by reductions in stomatal conductance to limit transpiration during water deficits (dehydration avoidance) (Ewers et al. 2005; McDowell et al. 2008; Sade et al. 2012; Arango-Velez et al. 2016). Mortality of isohydric species is more likely to occur following prolonged droughts of intermediate intensity, mainly through carbon starvation (McDowell et al. 2008; Choat et al. 2012). Pines have a lower ability to resist embolism than do spruces, but the water potential inducing the embolism threshold is higher (less negative) than that for trembling aspen and paper birch (Sperry and Sullivan 1992; Sperry et al. 1994; Choat et al. 2012). Although jack pine seedlings generally perform better than black spruce under dry conditions (Sirois 1993; Blake and Li 2003; Hébert et al. 2006), they could also be affected by water deficits. Indeed, in an experiment testing different water regimes, no seedlings survived after 3 months in a treatment involving two-fold less frequent watering compared to normal precipitation in eastern Canada (Splawinski et al. 2018). Buxton et al. (1985) observed that only $33 \%$ of jack pine seedlings survived after 9 days of drought, compared with 51\% survival for black spruce. These results contrast with previously cited studies (Sirois 1993; Blake and Li 2003), probably because of the differences in drought duration and intensity in the experiments, combined with the different hydraulic strategy responses. Jack pine seedlings would be more efficient at avoiding drought stress because of their larger, deeper and more rapidly growing root systems (Grossnickle and Blake 1986; Blake and Li 2003), but are less tolerant than black spruce to actual desiccation of their tissues (Buxton et al. 1985).

Trembling aspen Trembling aspen exhibits relatively isohydric behaviour (dehydration avoidance) during drought (Ewers et al. 2005). Aspen seedlings are particularly prone to desiccation prior to taproot development (Maini and Cayford 1968; Perala and Alm 1990), since their seeds contain little or no endosperm (Nagaraj 1952; Karrenberg et al. 2002). Germinants must rapidly establish photosynthetic leaf area to support root development and growth (Landhäusser et al. 2010). Post-fire trembling aspen recruitment can be particularly low in dry conditions in Alaska (Kasischke et al. 2007). However, once established, trembling aspen seedlings show greater biomass allocation to roots than do black spruce and jack pine (Peng and Dang 2003), a trait generally correlated with drought survival (Lloret et al. 1999; Paz 2003; Way and Sage 2008; Markesteijn and Poorter 2009). 
Paper birch Paper birch also exhibits relatively isohydric behaviour during drought (dehydration avoidance) (Ewers et al. 2005). This species, which is generally found on mesic sites (Landhäusser et al. 1996; Safford et al. 1990), is not resistant to cavitation (Sperry et al. 1994; Choat et al. 2012). Paper birch seedlings that were exposed to 6 days of water stress showed a decrease in shoot mass, but an increase in root-to-shoot ratio (Landhäusser et al. 1996).

\section{Maps of tree species vulnerability to climate change}

Maps showing the spatial distribution of vulnerability associated with post-fire recruitment for the four boreal species are presented in Fig. 2. Black spruce is the most widespread tree species in the Canadian boreal forest and appears to be particularly vulnerable to future climatic conditions. In large areas of northwestern Canada, CMI is projected to fall below the black spruce hydric envelope by 2041-2070, and fires are projected to increase (Fig. 2a, b). In some parts of central and eastern Canada, annual mean temperature is projected to be higher than the black spruce climatic envelope in 2041-2070 (Fig. 2a) and this vulnerability area is expected to strongly increase in 2071-2100 (Fig. 2b); these regions include areas with strong projected increases in fire frequency (in red on Fig. 2b). Black spruce will likely be vulnerable to both temperature and drought in central Canada in 2071-2100 (Fig. 2b). Jack pine post-fire regeneration could be affected by drought in large areas of northwestern Canada in 2041-2070 (Fig. 2c), and by both temperature and drought in central Canada by the end of the century (Fig. 2d). Jack pine post-fire recruitment is projected to be vulnerable to temperature increases over large areas of the eastern boreal forest in 2071-2100, including regions where burned areas are projected to increase (Fig. 2d). Trembling aspen is projected to be vulnerable to temperature for post-fire recruitment in southeastern Canada, and to drought in north-central and western Canada from 2041 (Fig. 2e, f). In the southern part of the boreal forest of central Canada, where fires are projected to be frequent, both temperature and drought are likely to affect aspen post-fire regeneration in 2071-2100 (Fig. 2f). Post-fire recruitment of paper birch is projected to be vulnerable to temperature increases in 2071-2100, mainly at the southernmost limit of the boreal forest in eastern Canada, especially in Québec, where the annual burned area could be $>4 \%$ (Fig. 2h). In northwestern Canada, where the burned area also exceeds $4 \%$ per year during the two projected periods, paper birch is expected to be vulnerable to drought (Fig. 2g, h).

\section{Discussion}

\section{Available knowledge and research gaps}

Our review highlights the sensitivity of post-fire recruitment and suggests that substantial increases in temperature and drought frequency could impair one or many of the recruitment stages. This review also highlights the variability in responses to temperature and water deficit between the four main boreal tree species. However, information is lacking for some regeneration stages and species, especially under conditions that are similar to what 

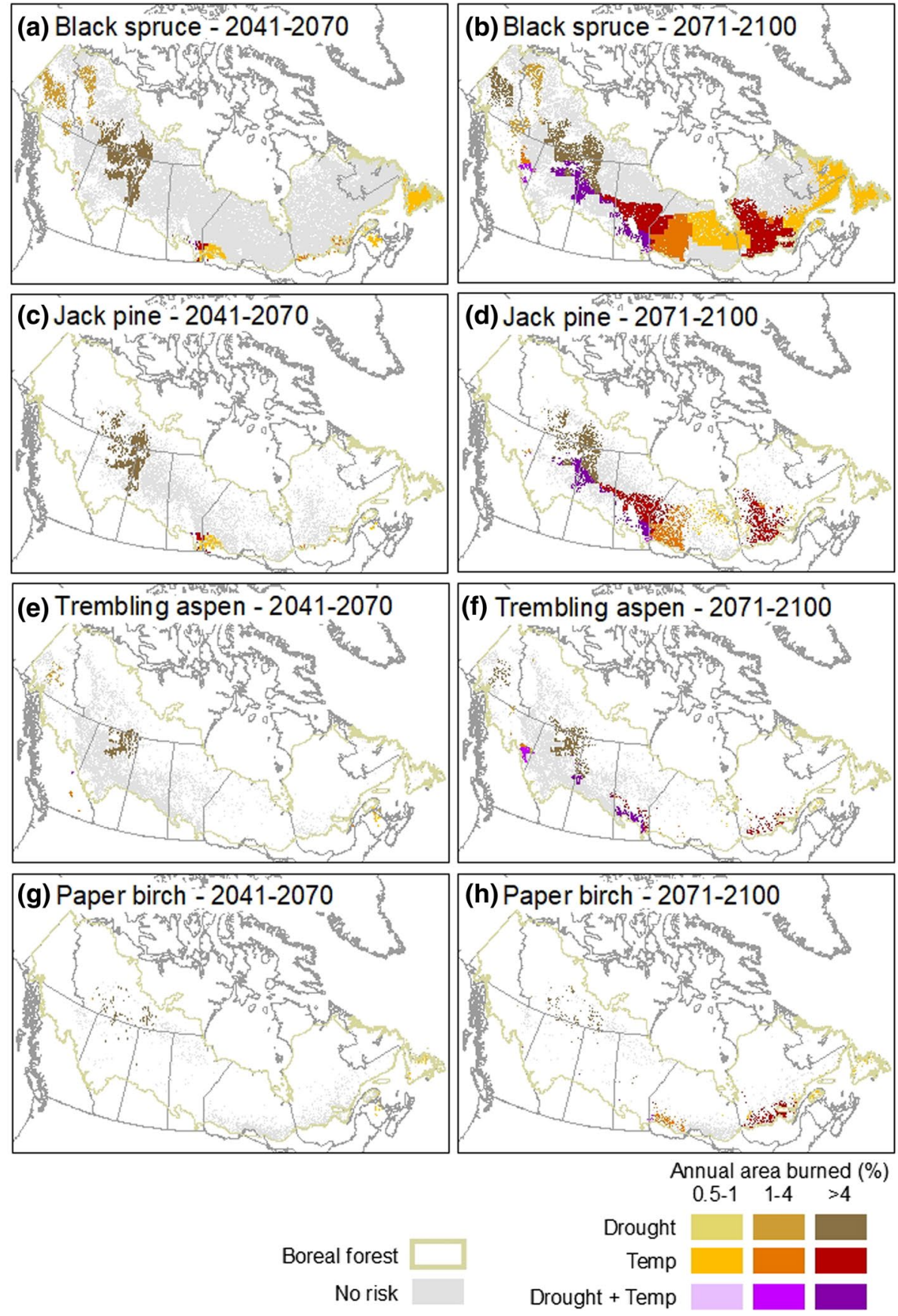

Fig. 2 Projected vulnerability associated with drought, temperature (Temp) and annual burned area (\%) for 2041-2070 and 2071-2100 for the post-fire recruitment of the four main tree species of the Canadian boreal forest: a black spruce, $\mathbf{b}$ jack pine, $\mathbf{c}$ trembling aspen, and $\mathbf{d}$ paper birch 
would be expected in the next few decades, such as very high temperatures, and severe and prolonged water deficits. Nevertheless, our review provides insights regarding future impacts of climate change on post-fire recruitment in the boreal forest (Table 2; Fig. 3).

\section{Seed production and availability}

Seed production is the least studied stage of recruitment. Many studies report that temperature increases could be beneficial to viable seed production (Despland and Houle 1997; Sirois 2000; Brown et al. 2019), but none have included very high temperature treatments for the four species, nor the potential effects of drought on seed production. Although a decrease in seed production or viability has been reported in response to high temperatures (Redmond et al. 2012; Gruwez et al. 2017) and drought (Mutke et al. 2005; Pérez-Ramos et al. 2010; Roland et al. 2014) for other species, it is not possible to anticipate these effects for the four boreal species that we reviewed.

\section{Seed germination}

More studies are available regarding the seed germination stage (Tables 1, S1 and S2). For the four boreal tree species, high temperatures increase seed germination rates up to a maximum of 30-33 ${ }^{\circ} \mathrm{C}$ (Faust 1936; Fraser 1970a, b; McDonough 1979; Fechner et al. 1981; Bevington 1986); germination rates decrease beyond this threshold. Germination is also strongly affected by the occurrence of drought, and tolerance to drought differs between species. Among the four species that were reviewed, jack pine is probably the most tolerant of harsh post-fire conditions, as it can germinate both at high temperatures and at low water availability (Fraser 1970b; Sirois 1993; Thomas and Wein 1985; Zasada et al. 1992; Boiffin and Munson 2013). The seeds of deciduous species show less ability to withstand moderate levels of moisture deficit than do those of conifers (Zasada et al. 1992). Still, post-fire jack pine recruitment failures have been reported in recent years (Pinno et al. 2013; Van Bogaert et al. 2015).

Furthermore, since seed viability of the four species is generally less than 1 year on the forest floor (Wilton 1963; Fraser 1976; Zasada et al. 1992), the period of adequate soil moisture for germination after fire is narrowed (Sirois 1995). Dry conditions during this period can thus prevent tree establishment from seeds (Zasada et al. 1992). Yet, species with long-distance seed dispersal, such as trembling aspen, could colonize burned patches over a long period after fire and germinate during drought-free years (Perala and Alm 1990; Harvey et al. 2016).

\section{Vegetative reproduction}

Vegetative reproduction is also a stage for which limited studies are available. Moderate temperature increases can positively affect sucker initiation (Maini and Horton 1964, 1966; Zasada and Schier 1973; Landhäusser et al. 2006), but sucker production is greatly reduced at $35{ }^{\circ} \mathrm{C}$ (Maini and Horton 1964, 1966). Drought appears to reduce trembling aspen sucker initiation (Hogg and Wein 2005), but information is insufficient to anticipate the effects of climate change (Tables $1, \mathrm{~S} 1$ and S2). The fact remains that the resprouting strategy allows aspen to better cope with post-fire drought stresses, compared to reproduction by seeds. 


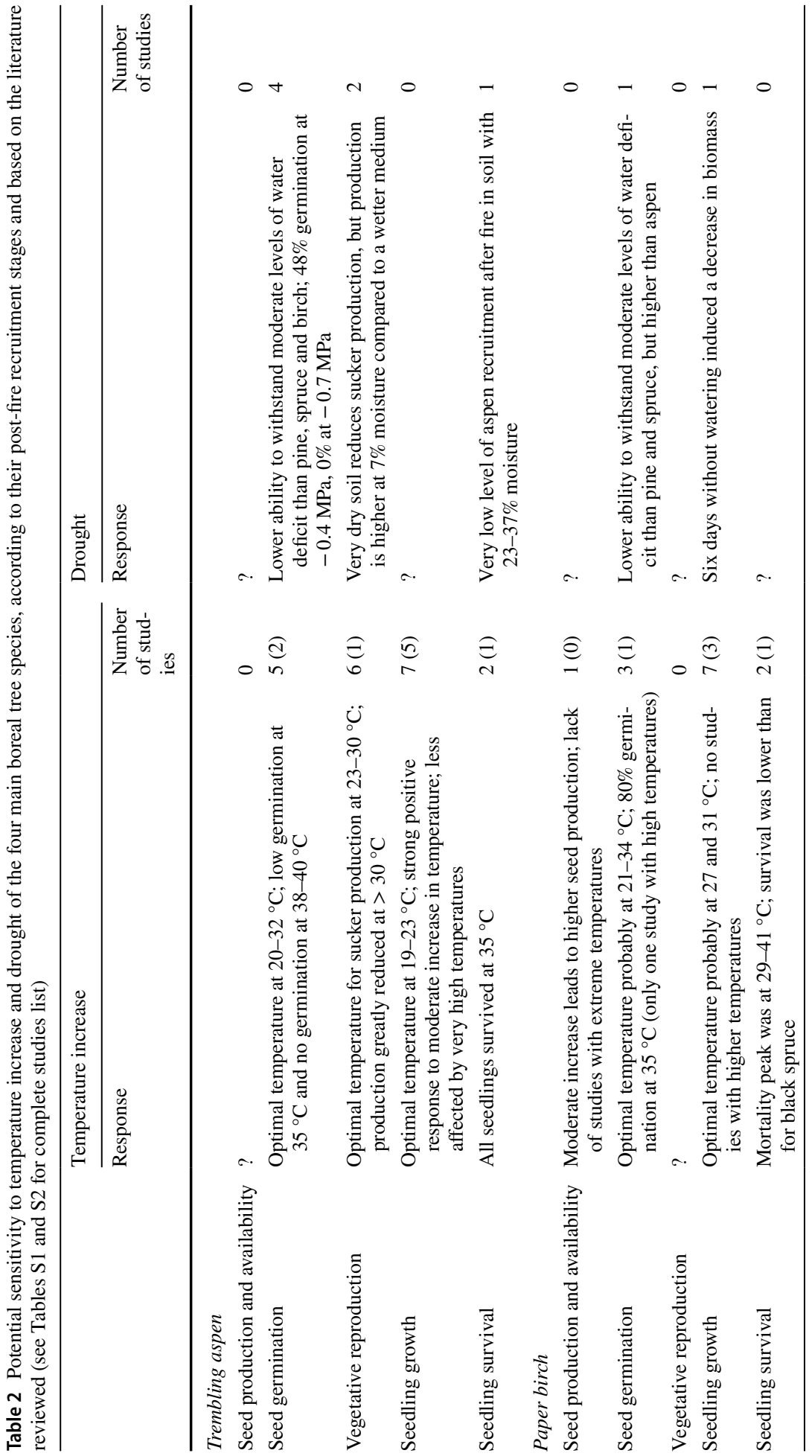




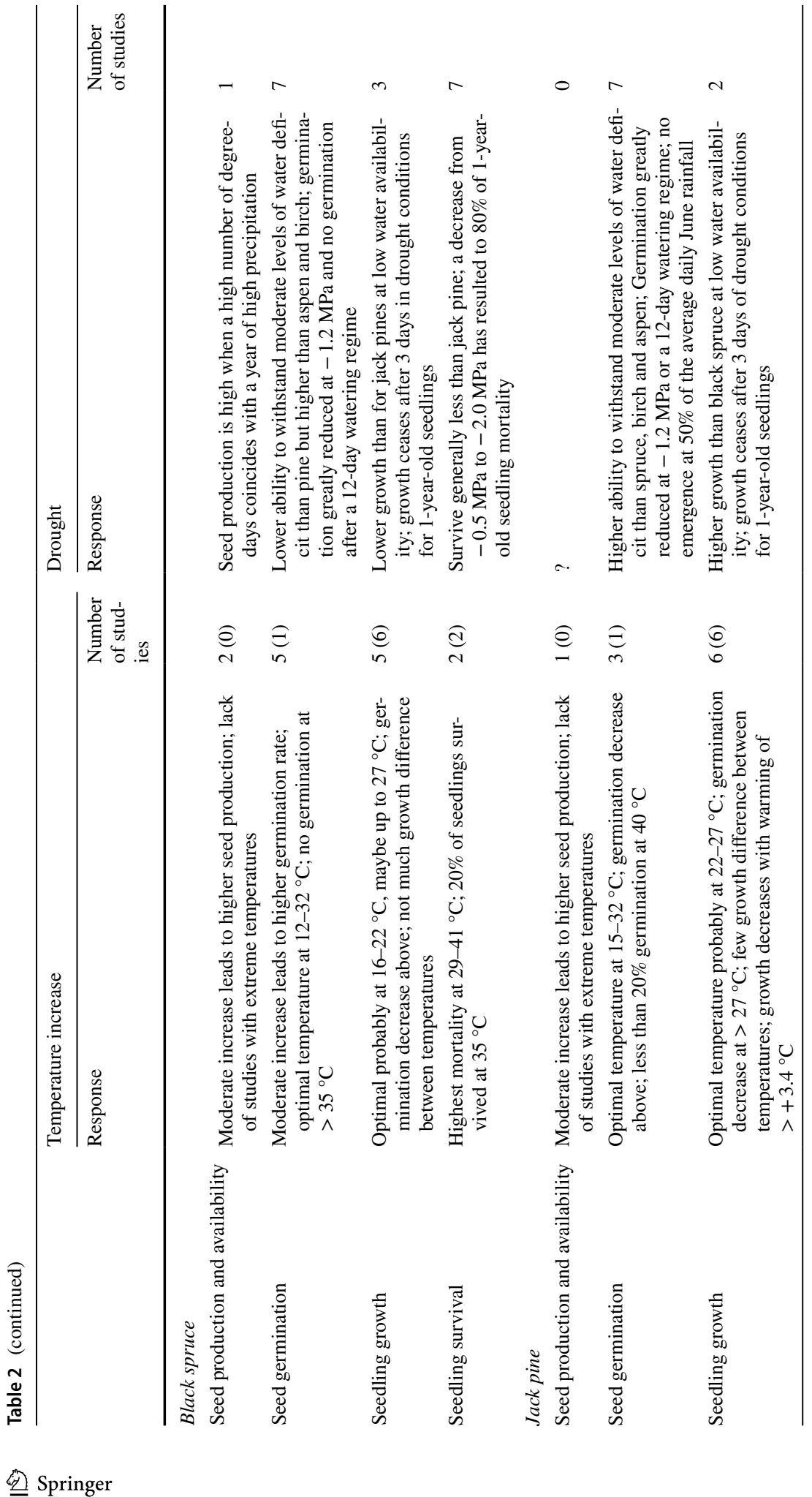




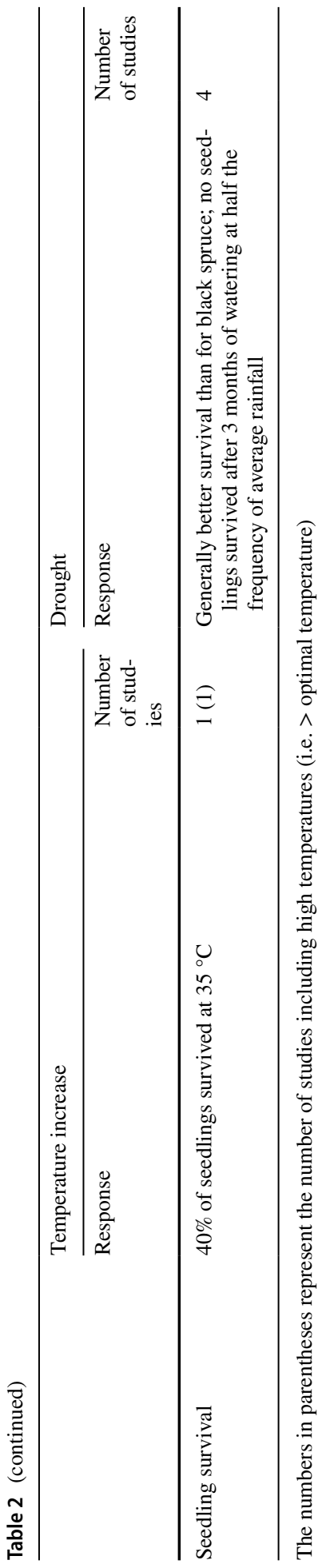


(a) Black spruce

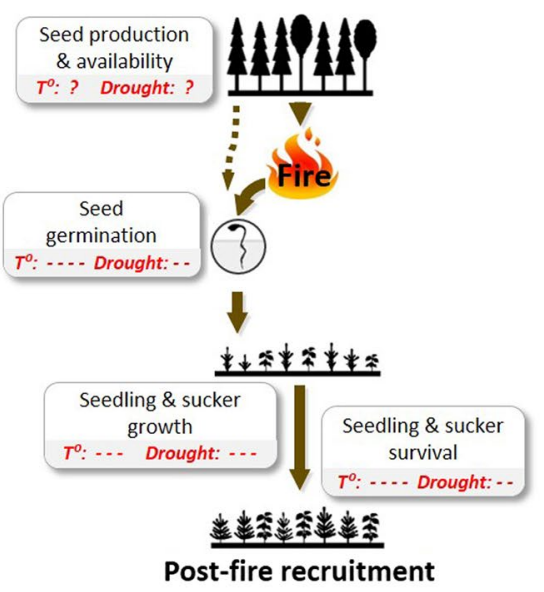

(c) Trembling aspen

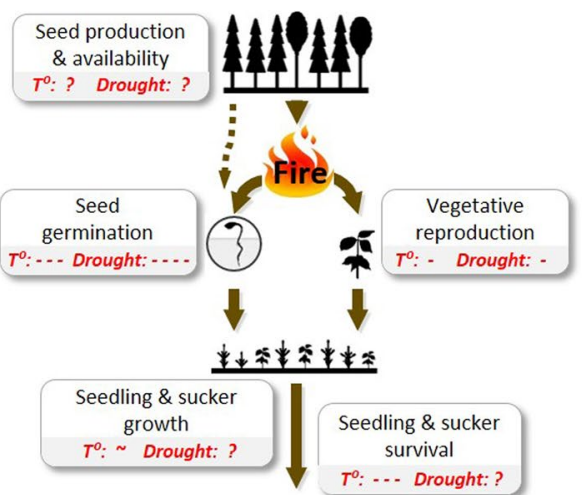

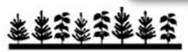

Post-fire recruitment (b) Jack pine
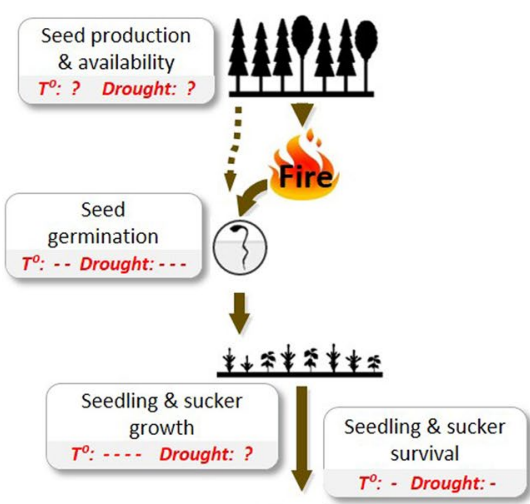

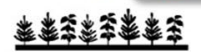

Post-fire recruitment

(d) Paper birch

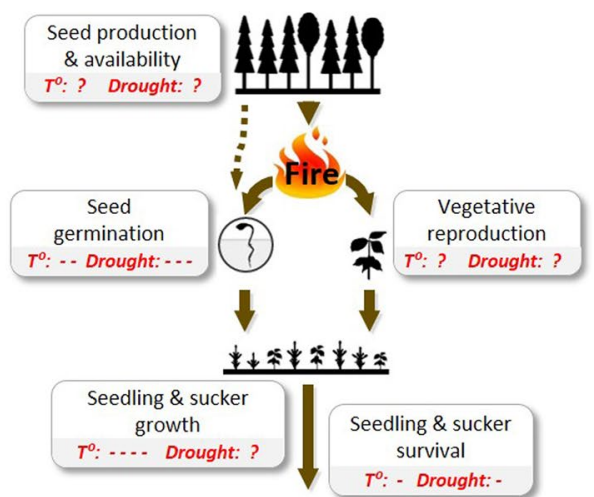

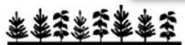

Post-fire recruitment

Fig. 3 Synthesis of the potential sensitivity to temperature increase and drought for four boreal tree species of North America, according to post-fire recruitment stages. Sensitivity to temperature $\left(\mathrm{T}^{\circ}\right)$ and drought are ranked among the species along a gradient that ranges from very sensitive (----) to insensitive ( ). Note that only the sensitivity of vegetative reproduction of trembling aspen has not been compared with the other species since no information was available on the vegetative reproduction of paper birch, and this stage is not present for the other species after fire

\section{Seedling and sucker growth and survival}

The seedling stage has been the most frequently studied in relation to climate variables, although knowledge of this stage is still insufficient, particularly regarding the effects of drought on deciduous species. The four boreal species have different optimum temperatures for seedling growth and they respond differently to temperature increases (Tables 1 and 
S1). Paper birch has the highest optimal temperature for seedling growth with $27-31{ }^{\circ} \mathrm{C}$, followed by jack pine, then by aspen and black spruce (Maini and Horton 1964, 1966; Heninger and White 1974; McDonough 1979; Tjoelker et al. 1998; Peng and Dang 2003; Dang and Cheng 2004; Zhang and Dang 2007; Way and Sage 2008). Trembling aspen seedlings survive better than do other boreal species to high temperature, showing no mortality when growing at $35^{\circ} \mathrm{C}$ (Viereck and Dyrness 1979; Peng and Dang 2003; Dang and Cheng 2004). Drought also affects the growth and survival of boreal recruits. Black spruce seedlings seem to be less resistant to intense drought than do jack pine seedlings (Sirois 1993; Blake and Li 2003). Trembling aspen recruitment can also be strongly affected by dry conditions after fire (Kasischke et al. 2007).

\section{Spatial distribution of species vulnerability to climate change}

Based on climate projections, temperatures above $35{ }^{\circ} \mathrm{C}$ and long-lasting droughts are expected to be more frequent in the coming decades. The period during which conditions will be suitable for seed germination following fire will likely be shortened. Seedling growth and survival after fires could also be seriously affected. These factors suggest a future increase in the risk of regeneration failure following fire due to high seedling mortality or insufficient numbers of germinants, especially considering that seed viability of boreal tree species is short (Wilton 1963; Zasada et al. 1992).

Specific effects of climate change on forest stands will also depend on location within the species range (Reich et al. 2015; Ibáñez et al. 2017; Chaste et al. 2019) and on the limiting factors of the local conditions (Boisvenue and Running 2006; Terrier et al. 2015; Nicklen et al. 2016; Pedlar and McKenney 2017). Temperature and drought projections for the current century show a high variability across Canada. Using the climatic envelopes of mature trees, we produced maps showing how post-fire recruitment processes are vulnerable to climate change; these maps allowed us to identify areas where tree species are most likely to be vulnerable to temperature and drought under future climate conditions. Given that climate niches of seedlings are generally narrower than those of mature trees (Hogg and Schwarz 1997; Jackson et al. 2009; Dobrowski et al. 2015), these maps probably underestimate the vulnerability of the species recruitment processes. In eastern Canada, tree species are expected to be more vulnerable to temperature increases, which are predicted to exceed the thresholds of the four species studied by the end of the century, while no significant decrease of the Climate Moisture Index (CMI) is projected (Fig. 2). Black spruce is likely the species with the lowest resistance to high temperatures, not only for the germination and seedling growth stages, but also for seedling survival; the projected temperatures will exceed the current climatic envelope of black spruce over large regions in eastern Canada. Combined with the projected increase in annual burned area, the risk of black spruce regeneration failure following fires in the next decades is high. Large areas of jack pine in eastern Canada are also projected to undergo temperature increases that exceed its climatic envelope. Although jack pine seeds and seedlings would be more heat-tolerant than those of black spruce, jack pine post-fire recruitment is expected to be impacted in large areas of eastern Canada because of the expected amplitude of warming. Post-fire recruitment of trembling aspen and paper birch could also be impacted by the end of the century, even if aspen seedlings generally have better survival rates under high-temperature conditions compared to other species (Peng and Dang 2003; Dang and Cheng 2004).

Forests in western Canada are projected to be affected mostly by drought by 2041-2070, while both temperature and drought increases will affect forests in central Canada by the 
end of the century (Fig. 2). Even in the northern territories, CMI is projected to be below the hydric envelope of black spruce. Many areas in western Canada are also projected to undergo an increase in fire frequency. Post-fire conditions will thus occur more frequently where drought will likely affect black spruce and jack pine recruitment. Recruitment processes of jack pine are more resistant to drought than those of other species, but very low CMIs are projected at the end of the century, which could seriously impair recruitment following fire.

Impacts of climate change have already been observed in some areas of the boreal forest, where deciduous species recruitment after fire has been favoured by climate change over the last few decades, at the expense of coniferous species (Bond-Lamberty et al. 2007; Johnstone et al. 2010a, b; Beck et al. 2011; Walker et al. 2017). Even in the absence of fire, a decrease in conifer establishment was observed in the southern Rocky Mountains of Canada between 1975 and 2010, which coincided with a general trend of rising summer temperatures and moisture deficits (Andrus et al. 2018). These observations concur with our vulnerability maps for the end of the century. Knowledge is lacking, however, regarding the effect of drought on specific recruitment stages, but some empirical evidence suggests greater tolerance to drought by aspen recruitment compared to conifers (Johnstone et al. 2010a, b; Harvey et al. 2016). It can be expected that, in the coming decades, this trend will continue and extend to other regions where vulnerability increases have been projected. As the temperatures will be warmer and drought periods more frequent or more severe, deciduous species might also suffer from these changes. Regeneration failures after fire are thus anticipated, leading to a shift from closed-canopy to open forests. The competition with more tolerant shrub species after fire could worsen this trend. Reduction in postfire regeneration density has been already observed in southern forests, particularly in dry areas (Donato et al. 2016; Rother and Veblen 2016; Stevens-Rumann et al. 2017). A rise in fire frequency increases the probability that fires will occur before trees have reached their optimal seed production (Splawinski et al. 2019). Yet, even when trees are sufficiently mature to produce seeds (or to reproduce vegetatively), future climate conditions are also expected to affect the recruitment process and increase the probability of post-fire regeneration failure. Therefore, we posit that the effects of climate change on regeneration will exacerbate the negative effects of fire frequency increases on post-fire recruitment.

\section{Conclusion}

Despite the importance of the regeneration phase for future boreal forest resilience (Kuuluvainen and Gauthier 2018), our literature review revealed significant gaps in understanding the potential regeneration responses to climate change. Globally, further research is needed to better understand the effect of climatic variables on recruitment stages of boreal tree species, including extreme conditions of temperature and moisture deficiencies that have been projected in the coming decades. In addition to growth chamber experiments, there is a need for in situ warming and drought-induced experiments. It would also be relevant to include seedling and sucker measurements within national forest inventory programs to monitor long-term trends in regeneration density, growth and survival.

We have anticipated the effects of climate change on post-fire recruitment to the best of our knowledge, but recognize that our analysis is incomplete. Not only is knowledge lacking for several stages of the recruitment process for certain species, our review did not consider some elements that could modify tree regeneration responses to climate change. For example, negative and positive impacts of climate change on insect pests, tree diseases 
and grazing animals (Pureswaran et al. 2015; Chapin et al. 2010; Frelich and Reich 2010) could also affect post-fire tree recruitment. Furthermore, tree species may eventually adapt to drier and warmer conditions. Indeed, trees from northern latitudes exhibit tolerances to temperature that differ from those of conspecific southern genotypes (Aitken et al 2008; Thomson et al. 2009; Pedlar and McKenney 2017). It can thus be asked whether climate change rates will allow trees sufficient time to adapt or acclimate to new conditions.

Despite this uncertainty about the anticipated effects of climate change, post-fire recruitment will likely be affected by warm and dry conditions, at least by the end of this century. In addition to indirect effects of fire frequency increases, the direct effects of a changing climate could have important repercussions on forest timber supply. Conifer-dominated forests may become less productive than they currently are, and timber supplies from deciduous species-dominated forests could also eventually decrease. The vulnerability maps that we produced are useful for identifying areas where species may be the most vulnerable to future climate conditions, where forest stands may be most at risk of regeneration failure, and where regeneration monitoring efforts should be prioritized. If recruitment proves to be deficient in these areas, adaptive silviculture practices such as the use of tree provenances adapted to future conditions (Nagel et al. 2017; Splawinski et al. 2019; Stevens-Rumann and Morgan 2019) could be used to mitigate the negative impacts of climate change on timber supply.

Acknowledgements This work was supported by an NSERC Strategic grant and a MITACS scholarship co-funded by NSERC and Ouranos. Additional financial support was provided by the UQAM Foundation (De Sève Foundation fellowship and TEMBEC forest ecology fellowship). We thank Yan Boulanger for providing fire and climate data, William F. J. Parsons and Mary Eady for English editing, and two anonymous reviewers for their useful comments on the manuscript. We also acknowledge the support of the Laurentian Forestry Centre and the Canadian Wood Fibre Centre of the Canadian Forest Service.

Open Access This article is distributed under the terms of the Creative Commons Attribution 4.0 International License (http://creativecommons.org/licenses/by/4.0/), which permits unrestricted use, distribution, and reproduction in any medium, provided you give appropriate credit to the original author(s) and the source, provide a link to the Creative Commons license, and indicate if changes were made.

\section{References}

Abe H, Nakai T (1999) Effect of the water status within a tree on tracheid morphogenesis in Cryptomeria japonica D. Don. Trees 14:124-129. https://doi.org/10.1007/PL00009758

Ackerman RF, Farrar JL (1965) The effect of light and temperature on the germination of jack pine and lodgepole pine seeds. Technical report no 5, Faculty of Forestry, University of Toronto

Aitken SN, Yeaman S, Holliday JA et al (2008) Adaptation, migration or extirpation: climate change outcomes for tree populations. Evol Appl 1:95-111. https://doi.org/10.1111/j.1752-4571.2007.00013.x

Allen RB, Hurst JM, Portier J, Richardson SJ (2014) Elevation-dependent responses of tree mast seeding to climate change over 45 years. Ecol Evol 4:3525-3537. https://doi.org/10.1002/ece3.1210

Anderegg WRL, Berry JA, Smith DD et al (2012) The roles of hydraulic and carbon stress in a widespread climate-induced forest die-off. Proc Natl Acad Sci 109:233-237. https://doi.org/10.1073/pnas.11078 91109

Anderegg WRL, Klein T, Bartlett M et al (2016) Meta-analysis reveals that hydraulic traits explain crossspecies patterns of drought-induced tree mortality across the globe. Proc Natl Acad Sci 113:50245029. https://doi.org/10.1073/pnas.1525678113

Andrus RA, Harvey BJ, Rodman KC et al (2018) Moisture availability limits subalpine tree establishment. Ecology 99:567-575. https://doi.org/10.1002/ecy.2134

Arango-Velez A, El Kayal W, Copeland CCJ et al (2016) Differences in defence responses of Pinus contorta and Pinus banksiana to the mountain pine beetle fungal associate Grosmannia clavigera are affected by water deficit. Plant Cell Environ 39:726-744. https://doi.org/10.1111/pce.12615 
Arend M, Fromm J (2007) Seasonal change in the drought response of wood cell development in poplar. Tree Physiol 27:985-992. https://doi.org/10.1093/treephys/27.7.985

Balducci L, Deslauriers A, Giovannelli A et al (2013) Effects of temperature and water deficit on cambial activity and woody ring features in Picea mariana saplings. Tree Physiol 33:1006-1017. https ://doi.org/10.1093/treephys/tpt073

Barber VA, Juday GP, Finney BP (2000) Reduced growth of Alaskan white spruce in the twentieth century from temperature-induced drought stress. Nature 405:668-673. https://doi.org/10.1038/35015 049

Barbero R, Abatzoglou JT, Larkin NK et al (2015) Climate change presents increased potential for very large fires in the contiguous United States. Int J Wildl Fire 24:892-899. https://doi.org/10.1071/ WF15083

Beaudoin A, Bernier PY, Villemaire P et al (2018) Tracking forest attributes across Canada between 2001 and 2011 using a $k$ nearest neighbors mapping approach applied to MODIS imagery. Can J For Res 48:85-93. https://doi.org/10.1139/cjfr-2017-0184

Beck PSA, Goetz SJ, Mack MC et al (2011) The impacts and implications of an intensifying fire regime on Alaskan boreal forest composition and albedo. Glob Chang Biol 17:2853-2866. https://doi.org/ 10.1111/j.1365-2486.2011.02412.x

Bell DM, Bradford JB, Lauenroth WK (2014) Early indicators of change: divergent climate envelopes between tree life stages imply range shifts in the western United States. Glob Ecol Biogeogr 23:168-180. https://doi.org/10.1111/geb.12109

Benowicz A, Guy R, Carlson MR, El-Kassaby YA (2001) Genetic variation among paper birch (Betula papyrifera Marsh.) populations in germination, frost hardiness, gas exchange and growth. Silvae Genet 50:7-13

Bevington J (1986) Geographic differences in the seed germination of paper birch (Betula papyrifera). Am J Bot 73:564-573

Black RA, Bliss LC (1980) Reproductive ecology of Picea mariana (Mill.) BSP., at tree line near Inuvik, Northwest territories, Canada. Ecol Monogr 50:331-354

Blake TJ, Li J (2003) Hydraulic adjustment in jack pine and black spruce seedlings under controlled cycles of dehydration and rehydration. Physiol Plant 117:532-539. https://doi.org/10.103 4/j.1399-3054.2003.00059.x

Boiffin J, Munson AD (2013) Three large fire years threaten resilience of closed crown black spruce forests in eastern Canada. Ecosphere 4:art56. https://doi.org/10.1890/es13-00038.1

Boisvenue C, Running SW (2006) Impacts of climate change on natural forest productivity-evidence since the middle of the 20th century. Glob Chang Biol 12:862-882. https://doi.org/10.111 1/j.1365-2486.2006.01134.x

Bonan GB (1989) Environmental factors and ecological processes controlling vegetation patterns in boreal forests. Landsc Ecol 3:111-130. https://doi.org/10.1007/BF00131174

Bonan GB (1992) Soil temperature as an ecological factor in boreal forests. In: Shugart HH, Leemans R, Bonan GB (eds) A systems analysis of the global forest. Cambridge University Press, Cambridge, New York, pp 126-143

Bond-Lamberty B, Peckham SD, Ahl DE, Gower ST (2007) Fire as the dominant driver of central Canadian boreal forest carbon balance. Nature 450:89-92. https://doi.org/10.1038/nature06272

Boulanger Y, Gauthier S, Burton PJ (2014) A refinement of models projecting future Canadian fire regimes using homogeneous fire regime zones. Can J For Res 44:365-376. https://doi.org/10.1139/ cjfr-2013-0372

Bradley AF, Noste NV, Fischer WC (1992) Fire ecology of forests and woodlands in Utah. US Department of Agriculture, Forest Service, Intermountain Research Station, General Technical Report INT-287

Brandt JP (2009) The extent of the North American boreal zone. Environ Rev 17:101-161. https://doi. org/10.1139/A09-004

Briand CH, Schwilk DW, Gauthier S, Bergeron Y (2015) Does fire regime influence life history traits of jack pine in the southern boreal forest of Québec, Canada? Plant Ecol 216:157-164. https://doi. org/10.1007/s11258-014-0424-X

Briffa KR, Schweingruber FH, Jone PD et al (1998) Reduced sensitivity of recent tree-growth to temperature at high northern latitudes. Nature 391:678-682

Brown CD, Dufour-Tremblay G, Jameson RG et al (2019) Reproduction as a bottleneck to treeline advance across the circumarctic forest tundra ecotone. Ecography 42:137-147. https://doi. org/10.1111/ecog.03733

Buxton GF, Cyr DR, Dumbroff EB, Webb DP (1985) Physiological responses of three northern conifers to rapid and slow induction of moisture stress. Can J Bot 63:1171-1176. https://doi.org/10.1139/ b85-162 
Cannell MGR, Smith RI (1986) Climatic warming, spring budburst and frost damage on trees. J Appl Ecol 23:177-191

Chapin FS III, McGuire AD, Ruess RW et al (2010) Resilience of Alaska's boreal forest to climatic change. Can J For Res 40:1360-1370. https://doi.org/10.1139/X10-074

Charron I, Greene DF (2002) Post-wildfire seedbeds and tree establishment in the southern mixedwood boreal forest. Geography 32:1607-1615. https://doi.org/10.1139/X02-085

Chaste E, Girardin MP, Kaplan JO et al (2019) Increases in heat-induced tree mortality could drive reductions of biomass resources in Canada's managed boreal forest. Landsc Ecol 34:403-426. https://doi. org/10.1007/s10980-019-00780-4

Choat B, Jansen S, Brodribb TJ et al (2012) Global convergence in the vulnerability of forests to drought. Nature 491:752-756. https://doi.org/10.1038/nature11688

Chrosciewicz Z (1974) Evaluation of fire-produced seedbeds for jack pine regeneration in central Ontario. Can J For Res 4:455-457

D’Orangeville L, Maxwell J, Kneeshaw D et al (2018) Drought timing and local climate determine the sensitivity of eastern temperate forests to drought. Glob Chang Biol 24:2339-2351. https://doi. org/10.1111/gcb.14096

Danby RK, Hik DS (2007) Responses of white spruce (Picea glauca) to experimental warming at a subarctic alpine treeline. Glob Chang Biol 13:437-451. https://doi.org/10.1111/j.1365-2486.2006.01302.x

Dang QL, Cheng S (2004) Effects of soil temperature on ecophysiological traits in seedlings of four boreal tree species. For Ecol Manage 194:379-387. https://doi.org/10.1016/j.foreco.2004.03.004

Day ME, Schedlbauer JL, Livingston WH et al (2005) Influence of seedbed, light environment, and elevated night temperature on growth and carbon allocation in pitch pine (Pinus rigida) and jack pine (Pinus banksiana) seedlings. For Ecol Manage 205:59-71. https://doi.org/10.1016/j.foreco.2004.10.004

de Luis M, Novak K, Raventós J et al (2011) Cambial activity, wood formation and sapling survival of Pinus halepensis exposed to different irrigation regimes. For Ecol Manage 262:1630-1638. https:// doi.org/10.1016/j.foreco.2011.07.013

DeLong SC, Tanner D (1996) Managing the pattern of forest harvest: lessons from wildfire. Biodivers Conserv 5:1191-1205. https://doi.org/10.1007/bf00051571

Despland E, Houle G (1997) Climate influences on growth and reproduction of Pinus banksiana (Pinaceae) at the limit of the species distribution in eastern North America. Am J Bot 84:928-937. https://doi. org/10.2307/2446283

Dobrowski SZ, Swanson AK, Abatzoglou JT et al (2015) Forest structure and species traits mediate projected recruitment declines in western US tree species. Glob Ecol Biogeogr 24:917-927. https://doi. org/10.1111/geb.12302

Dodson EK, Root HT (2013) Conifer regeneration following stand-replacing wildfire varies along an elevation gradient in a ponderosa pine forest, Oregon, USA. For Ecol Manage 302:163-170. https://doi. org/10.1016/j.foreco.2013.03.050

Donato DC, Harvey BJ, Turner MG (2016) Regeneration of montane forests a quarter-century after the 1988 Yellowstone fires: a fire-catalyzed shift in lower treelines? Ecosphere 7:e01410. https://doi. org/10.1002/ecs2.1410

Drobyshev I, Övergaard R, Saygin I et al (2010) Masting behaviour and dendrochronology of European beech (Fagus sylvatica L.) in southern Sweden. For Ecol Manage 259:2160-2171. https://doi. org/10.1016/j.foreco.2010.01.037

Duchesne S, Sirois L (1995) Phase initiale de régénération après feu des populations conifériennes subarctiques. Can J Bot 25:307-318

Dyrness CT, Norum RA (1983) The effects of experimental fires on black spruce forest floors in interior Alaska. Can J For Res 13:879-893

Ewers BE, Gower ST, Bond-Lamberty B, Wang CK (2005) Effects of stand age and tree species composition on transpiration and canopy conductance of boreal forests. Plant Cell Environ 28:660-678

Faust ME (1936) Germination of Populus grandidentata and P. tremuloides, with particular reference to oxygen consumption. Bot Gaz 97:808-821

Fechner GH, Burr KE, Myers J (1981) Effects of storage, temperature, and moisture stress on seed germination and early seedling development of trembling aspen. Can J Res 11:718-722

Feddema JJ, Mast JN, Savage M (2013) Modeling high-severity fire, drought and climate change impacts on ponderosa pine regeneration. Ecol Modell 253:56-69. https://doi.org/10.1016/j.ecolm odel.2012.12.029

Flannigan M, Cantin AS, De Groot WJ et al (2013) Global wildland fire season severity in the 21st century. For Ecol Manage 294:54-61. https://doi.org/10.1016/j.foreco.2012.10.022

Foster DR, King GA (1986) Vegetation pattern and diversity in S.E. Labrador, Canada: Betula papyrifera (birch) forest development in relation to fire history and physiography. J Ecol 74:465-483 
Fraser JW (1970a) Cardinal temperatures for germination of six provenances of black spruce seed. Information report PS-X-23, Canadian Department of Fisheries and Forestry, Ottawa, Ontario

Fraser JW (1970b) Cardinal temperatures for germination of white, red and jack pine seed. Information report PS-X-15, Canadian Department of Fisheries and Forestry, Ottawa, Ontario

Fraser JW (1976) Viability of black spruce seed in or on a boreal forest seedbed. For Chron 52:229-231. https://doi.org/10.5558/tfc52229-5

Fraser EC, Lieffers VJ, Landhäusser SM, Frey BR (2002) Soil nutrition and temperature as drivers of root suckering in trembling aspen. Can J For Res 32:1685-1691. https://doi.org/10.1139/X02-080

Frelich LE, Reich PB (2010) Will environmental changes reinforce the impact of global warming on the prairie-forest border of central North America? Front Ecol Environ 8:371-378. https://doi. org/10.1890/080191

Frey BR, Lieffers VJ, Landhäusser SM et al (2003) An analysis of sucker regeneration of trembling aspen. Can J For Res 33:1169-1179. https://doi.org/10.1139/x03-053

Girard F, Payette S, Gagnon R (2009) Origin of the lichen-spruce woodland in the closed-crown forest zone of eastern Canada. Glob Ecol Biogeogr 18:291-303. https://doi.org/10.1111/j.1466-8238.2009.00449 .X

Greene DF, Zasada JC, Sirois L et al (1999) A review of the regeneration dynamics of North American boreal forest tree species. Can J For Res 29:824-839. https://doi.org/10.1139/x98-112

Greenwood MS, Livingston WH, Day ME et al (2002) Contrasting modes of survival by jack and pitch pine at a common range limit. Can J For Res 32:1662-1674. https://doi.org/10.1139/x02-088

Grenier M, Sirois L (2009) Reproductive development and seed ripening in Betula papyrifera along an altitudinal thermal gradient in eastern Appalachia (Canada). Botany 87:492-500. https://doi.org/10.1139/ B09-018

Grossnickle SC, Blake TJ (1986) Environmental and physiological control of needle conductance for bareroot black spruce, white spruce, and jack pine seedlings on boreal cutover sites. Can J Bot 64:943949. https://doi.org/10.1139/b86-126

Grubb PJ (1977) The maintenance of species-richness in plant communities: the importance of the regeneration niche. Biol Rev 52:107-145. https://doi.org/10.1111/j.1469-185X.1977.tb01347.x

Gruwez R, De Frenne P, De Schrijver A et al (2017) Climate warming and atmospheric deposition affect seed viability of common juniper (Juniperus communis) via their impact on the nutrient status of the plant. Ecol Res 32:135-144. https://doi.org/10.1007/s11284-016-1422-3

Hacke UG, Jansen S (2009) Embolism resistance of three boreal conifer species varies with pit structure. New Phytol 182:675-686. https://doi.org/10.1111/j.1469-8137.2009.02783.x

Harvey BJ, Donato DC, Turner MG (2016) High and dry: postfire drought and large stand-replacing burn patches reduce postfire tree regeneration in subalpine forests. Glob Ecol Biogeogr 25:655-669. https ://doi.org/10.1111/geb.12443

He T, Pausas JG, Belcher CM et al (2012) Fire-adapted traits of Pinus arose in the fiery Cretaceous. New Phytol 194:751-759. https://doi.org/10.1111/j.1469-8137.2012.04079.x

Hébert F, Boucher J-F, Bernier PY, Lord D (2006) Growth response and water relations of 3-year-old planted black spruce and jack pine seedlings in site prepared lichen woodlands. For Ecol Manage 223:226-236. https://doi.org/10.1016/j.foreco.2005.11.005

Heikkinen RK, Luoto M, Araujo MB et al (2006) Methods and uncertainties in bioclimatic envelope modelling under climate change. Prog Phys Geogr 30:751-777

Heninger RL, White DP (1974) Tree seedling growth at different soil temperatures. For Sci 20:363-367

Henttonen H, Kanninen M, Nygren M, Ojansuu R (1986) The maturation of Pinus sylvestris seeds in relation to temperature climate in Northern Finland. Scand J For Res 1:243-249. https://doi. org/10.1080/02827588609382415

Herr DG, Duchesne LC (1995) Jack pine (Pinus banksiana) seedling emergence is affected by organic horizon removal, ashes, soil, water and shade. Water Air Soil Pollut 82:147-154. https://doi.org/10.1007/ BF01182828

Hesketh M, Greene DF, Pounden E (2009) Early establishment of conifer recruits in the northern Rocky Mountains as a function of postfire duff depth. Can J For Res 39:2059-2064. https://doi.org/10.1139/ X09-120

Hobbie SE, Chapin FS III (1998) An experimental test of limits to tree establishment in Arctic tundra. J Ecol 86:461-499. https://doi.org/10.1046/j.1365-2745.1998.00278.x

Hogg EH, Schwarz AG (1997) Regeneration of planted conifers across climatic moisture gradients on the Canadian prairies: implications for distribution and climate change. J Biogeogr 24:527-534. https:// doi.org/10.1111/j.1365-2699.1997.00138.x

Hogg EH, Wein RW (2005) Impacts of drought on forest growth and regeneration following fire in southwestern Yukon, Canada. Can J For Res 35:2141-2150. https://doi.org/10.1139/X05-120 
Hungerford RD (1988) Soil temperatures and suckering in burned and unburned aspen stands in Idaho. US Department of Agriculture, Forest Service, Research note INT-378

Ibáñez I, Katz DSW, Lee BR (2017) The contrasting effects of short-term climate change on the early recruitment of tree species. Oecologia 184:701-713. https://doi.org/10.1007/s00442-017-3889-1

Jackson ST, Betancourt JL, Booth RK, Gray ST (2009) Ecology and the ratchet of events: climate variability, niche dimensions, and species distributions. Proc Natl Acad Sci 106:19685-19692. https:// doi.org/10.1073/pnas.0901644106

Johnson EA, Morin H, Miyanishi K et al (2003) A process approach to understanding disturbance and forest dynamics for sustainable forestry. In: Burton PJ, Messier C, Smith DW, Adamowicz WL (eds) Towards sustainable management of the boreal forest. NRC Research Press, Ottawa, pp 261-306

Johnstone JF, Chapin FS III (2006a) Effects of soil burn severity on post-fire tree recruitment in boreal forest. Ecosystems 9:14-31. https://doi.org/10.1007/s10021-004-0042-x

Johnstone JF, Chapin FS III (2006b) Fire interval effects on successional trajectory in boreal forests of northwest Canada. Ecosystems 9:268-277. https://doi.org/10.1007/s10021-005-0061-2

Johnstone JF, Hollingsworth TN, Chapin FS III, Mack MC (2010a) Changes in fire regime break the legacy lock on successional trajectories in Alaskan boreal forest. Glob Chang Biol 16:1281-1295. https://doi.org/10.1111/j.1365-2486.2009.02051.x

Johnstone JF, McIntire EJB, Pedersen EJ et al (2010b) A sensitive slope: estimating landscape patterns of forest resilience in a changing climate. Ecosphere 1:art14. https://doi.org/10.1890/es10-00102.1

Karrenberg S, Edwards PJ, Kollmann J (2002) The life history of Salicaceae living in the active zone of floodplains. Freshw Biol 47:733-748. https://doi.org/10.1046/j.1365-2427.2002.00894.x

Kasischke ES, Bourgeau-Chavez LL, Johnstone JF (2007) Assessing spatial and temporal variations in surface soil moisture in fire-disturbed black spruce forests in Interior Alaska using spaceborne synthetic aperture radar imagery-implications for post-fire tree recruitment. Remote Sens Environ 108:42-58. https://doi.org/10.1016/j.rse.2006.10.020

Koenig WD, Knops JMH (1998) Scale of mast-seeding and tree-ring growth. Nature 396:225. https:// doi.org/10.1038/24290

Körner C (2003) Carbon limitation in trees. J Ecol 91:4-17. https://doi.org/10.104 6/j.1365-2745.2003.00742.x

Krugman SL, Stein WI, Schmitt DM (1974) Seed biology. In: Schopmeyer CS (ed) Seeds of woody plants in the United States. US Department of Agriculture, Forest Service, Agricultural Handbook 450, pp 5-40

Kuuluvainen T, Gauthier S (2018) Young and old forest in the boreal: critical stages of ecosystem dynamics and management under global change. For Ecosyst. 5:1-15. https://doi.org/10.1186/ s40663-018-0142-2

Landhäusser SM, Lieffers VJ (1998) Growth of Populus tremuloides in association with Calamagrostis canadensis. Can J For Res 28:396-401. https://doi.org/10.1139/x98-006

Landhäusser SM, Wein RW, Lange P (1996) Gas exchange and growth of three arctic tree-line tree species under different soil temperature and drought preconditioning regimes. Can J Bot 74:686-693. https://doi.org/10.1139/b96-087

Landhäusser SM, Lieffers VJ, Mulak T (2006) Effects of soil temperature and time of decapitation on sucker initiation of intact Populus tremuloides root systems. Scand J For Res 21:299-305. https:// doi.org/10.1080/02827580600813313

Landhäusser SM, Deshaies D, Lieffers VJ (2010) Disturbance facilitates rapid range expansion of aspen into higher elevations of the Rocky Mountains under a warming climate. J Biogeogr 37:68-76. https://doi.org/10.1111/j.1365-2699.2009.02182.x

Lavertu D, Mauffette Y, Bergeron Y (1994) Effects of stand age and litter removal on the regeneration of Populus tremuloides. J Veg Sci 5:561-568

Lenoir J, Gégout J-C, Pierrat J-C et al (2009) Differences between tree species seedling and adult altitudinal distribution in mountain forests during the recent warm period (1986-2006). Ecography 32:765-777. https://doi.org/10.1111/j.1600-0587.2009.06046

Lloret F, Casanovas C, Peñuelas J (1999) Seedling survival of Mediterranean shrubland species in relation to root: shoot ratio, seed size and water and nitrogen use. Funct Ecol 13:210-216. https://doi. org/10.1046/j.1365-2435.1999.00309.x

Lloyd AH, Fastie CL (2002) Spatial and temporal variability in the growth and climate response of treeline trees in Alaska. Clim Change 52:481-509. https://doi.org/10.1023/a:1014278819094

Lucas-Borja ME, Vacchiano G (2018) Interactions between climate, growth and seed production in Spanish black pine (Pinus nigra Arn. ssp. salzmannii) forests in Cuenca Mountains (Spain). New For 49:399-414. https://doi.org/10.1007/s11056-018-9626-8 
Maini JS, Cayford JH (1968) Growth and utilization of poplars in Canada. Department of Forestry and Rural Development, Departmental Publication No. 1205

Maini JS, Horton KW (1964) Influence of temperature and moisture on formation and initial growth of Populus tremuloides suckers. Department of Forestry Canada, Richmond Hill

Maini JS, Horton KW (1966) Vegetative propagation of Populus spp. 1. Influence of temperature on formation and initial growth of aspen suckers. Can J Bot 44:1183-1189

Markesteijn L, Poorter L (2009) Seedling root morphology and biomass allocation of 62 tropical tree species in relation to drought- and shade-tolerance. J Ecol 97:311-325. https://doi.org/10.111 1/j.1365-2745.2008.01466.x

McDonough WT (1979) Quaking aspen-seed germination and early seedling growth. US Department of Agriculture, Forest Service, Research Paper INT-234 1-14

McDowell N et al (2008) Mechanisms of plants mortality during drought: Why do some plants survive while others succumb to drought? New Phytol 178:719-739. https://doi.org/10.1016/j.biocon.2016.01.028

McKenney DW, Pedlar JH, Lawrence K et al (2007) Beyond traditional hardiness zones: using climate envelopes to map plant range limits. Bioscience 57:929. https://doi.org/10.1641/B571105

Mckenney D, Pedlar J, Hutchinson M et al (2013) Spatial climate models for Canada's forestry community. For Chron 89:659-663. https://doi.org/10.5558/tfc2013-118

Messaoud Y, Bergeron Y, Asselin H (2007) Reproductive potential of balsam fir (Abies balsamea), white spruce (Picea glauca), and black spruce (P. mariana) at the ecotone between mixedwood and coniferous forests in the boreal zone of western Quebec. Am J Bot 94:746-754

Meunier C, Sirois L, Bégin Y (2007) Climate and Picea mariana seed maturation relationships: a multiscale perspective. Ecol Monogr 77:361-376

Miyanishi K, Johnson EA (2002) Process and patterns of duff consumption in the mixedwood boreal forest. Can J For Res 32:1285-1295. https://doi.org/10.1139/X02-051

Morin X, Augspurger C, Chuine I (2007) Process-based modeling of species' distributions: What limits temperate tree species' range boundaries? Ecology 88:2280-2291. https://doi.org/10.1890/06-1591.1

Moss M, Hermanutz L (2009) Postfire seedling recruitment at the southern limit of lichen woodland. Can J For Res 39:2299-2306. https://doi.org/10.1139/X09-150

Munier A, Hermanutz L, Jacobs JD, Lewis K (2010) The interacting effects of temperature, ground disturbance, and herbivory on seedling establishment: implications for treeline advance with climate warming. Plant Ecol 210:19-30. https://doi.org/10.1007/s11258-010-9724-y

Mutke S, Gordo J, Gil L (2005) Variability of Mediterranean Stone pine cone production: yield loss as response to climate change. Agric For Meteorol 132:263-272. https://doi.org/10.1016/j.agrfo rmet.2005.08.002

Myneni RB, Keeling CD, Tucker CJ et al (1997) Increased plant growth in the northern high latitudes from 1981 to 1991 . Nature 386:698-702

Nagaraj M (1952) Floral morphology of Populus deltoides and P. tremuloides. Bot Gaz 114:222-243

Nagel LM, Palik BJ, Battaglia MA et al (2017) Adaptive silviculture for climate change: a national experiment in manager-scientist partnerships to apply an adaptation framework. J For 115:167-178. https:// doi.org/10.5849/jof.16-039

Nardini A, Battistuzzo M, Savi T (2013) Shoot desiccation and hydraulic failure in temperate woody angiosperms during an extreme summer drought. New Phytol 200:322-329. https://doi.org/10.1111/ nph. 12288

Nicklen EF, Roland CA, Ruess RW et al (2016) Local site conditions drive climate-growth responses of Picea mariana and Picea glauca in interior Alaska. Ecosphere 7:e01507. https://doi.org/10.1002/ ecs 2.1507

Nussbaumer A, Waldner P, Apuhtin V et al (2018) Impact of weather cues and resource dynamics on mast occurrence in the main forest tree species in Europe. For Ecol Manage 429:336-350. https://doi. org/10.1016/j.foreco.2018.07.011

O’Brien MJ, Peréz-Aviles D, Powers JS (2018) Resilience of seed production to a severe El Niño-induced drought across functional groups and dispersal types. Glob Chang Biol 24:5270-5280. https://doi. org/10.1111/gcb.14416

Ols C, Hofgaard A, Bergeron Y, Drobyshev I (2016) Previous growing season climate controls the occurrence of black spruce growth anomalies in boreal forests of Eastern Canada. Can J For Res 46:696-705

Pallardy SG (2008) Physiology of woody plants, 3rd edn. Elsevier, New York

Pappas C, Matheny AM, Baltzer JL et al (2018) Boreal tree hydrodynamics: asynchronous, diverging, yet complementary. Tree Physiol 38:953-964. https://doi.org/10.1093/treephys/tpy043

Paragi TF, Haggstrom DA (2007) Short-term responses of aspen to fire and mechanical treatments in interior Alaska. North J Appl For 24:153-157 
Parantainen A, Pulkkinen P (2002) Pollen viability of Scots pine (Pinus sylvestris) in different temperature conditions: high levels of variation among and within latitudes. For Ecol Manage 167:149-160. https ://doi.org/10.1016/S0378-1127(01)00722-8

Payette S, Delwaide A (2018) Tamm review: the North-American lichen woodland. For Ecol Manage 417:167-183. https://doi.org/10.1016/j.foreco.2018.02.043

Paz H (2003) Root/shoot allocation and root architecture in seedlings: variation among forest sites, microhabitats, and ecological groups. Biotropica 35:318-332

Pedlar JH, McKenney DW (2017) Assessing the anticipated growth response of northern conifer populations to a warming climate. Sci Rep 7:43881. https://doi.org/10.1038/srep43881

Peng YY, Dang Q (2003) Effects of soil temperature on biomass production and allocation in seedlings of four boreal tree species. For Ecol Manage 180:1-9

Perala DA, Alm AA (1990) Reproductive ecology of birch: a review. For Ecol Manage 32:1-38. https://doi. org/10.1016/0378-1127(90)90104-J

Pérez-Ramos IM, Ourcival JM, Limousin JM, Rambal S (2010) Mast seeding under increasing drought: results from a long-term data set and from a rainfall exclusion experiment. Ecology 91:3057-3068

Pigott CD, Huntley JP (1981) Factors controlling the distribution of Tilia cordata at the northern limits of its geographical range III. Nature and causes of seed sterility. New Phytol 87:817-839. https://doi. org/10.1111/j.1469-8137.1981.tb01716.x

Pinno BD, Errington RC, Thompson DK (2013) Young jack pine and high severity fire combine to create potentially expansive areas of understocked forest. For Ecol Manage 310:517-522. https://doi. org/10.1016/j.foreco.2013.08.055

Prescott CE, Maynard DG, Laiho R (2000) Humus in northern forests: friend or foe? For Ecol Manage 133:23-36. https://doi.org/10.1016/S0378-1127(99)00295-9

Pureswaran DS, De Grandpré L, Paré D et al (2015) Climate-induced changes in host tree-insect phenology may drive ecological. Ecology 96:1480-1491. https://doi.org/10.1890/07-1861.1

Redmond MD, Forcella F, Barger NN (2012) Declines in pinyon pine cone production associated with regional warming. Ecosphere 3:art120. https://doi.org/10.1890/es12-00306.1

Régnière J, St-Amant R (2007) Stochastic simulation of daily air temperature and precipitation from monthly normals in North America north of Mexico. Int J Biometeorol 51:415-430. https://doi. org/10.1007/s00484-006-0078-z

Reich PB, Sendall KM, Rice K et al (2015) Geographic range predicts photosynthetic and growth response to warming in co-occurring tree species. Nat Clim Chang 5:148-152. https://doi.org/10.1038/nclim ate 2497

Renard SM, McIntire EJB, Fajardo A (2016) Winter conditions-not summer temperature-influence establishment of seedlings at white spruce alpine treeline in Eastern Quebec. J Veg Sci 27:29-39. https://doi.org/10.1111/jvs. 12347

Rodrigo J (2000) Spring frosts in deciduous fruit trees-morphological damage and flower hardiness. Sci Hortic 85:155-173. https://doi.org/10.1016/S0304-4238(99)00150-8

Rogers BM, Neilson RP, Drapek R et al (2011) Impacts of climate change on fire regimes and carbon stocks of the U.S. Pacific Northwest. J Geophys Res Biogeosci 116:G03037. https://doi.org/10.1029/2011j g001695

Roland CA, Schmidt JH, Johnstone JF (2014) Climate sensitivity of reproduction in a mast-seeding boreal conifer across its distributional range from lowland to treeline forests. Oecologia 174:665-677. https ://doi.org/10.1007/s00442-013-2821-6

Rossi S, Deslauriers A, Griçar J et al (2008) Critical temperatures for xylogenesis in conifers of cold climates. Glob Ecol Biogeogr 17:696-707. https://doi.org/10.1111/j.1466-8238.2008.00417.x

Rossi S, Simard S, Rathgeber CBK et al (2009) Effects of a 20-day-long dry period on cambial and apical meristem growth in Abies balsamea seedlings. Trees 23:85-93. https://doi.org/10.1007/s0046 8-008-0257-0

Rossi S, Morin H, Deslauriers A, Plourde PY (2011) Predicting xylem phenology in black spruce under climate warming. Glob Chang Biol 17:614-625. https://doi.org/10.1111/j.1365-2486.2010.02191.x

Rother MT, Veblen TT (2016) Limited conifer regeneration following wildfires in dry ponderosa pine forests of the Colorado Front Range. Ecosphere. https://doi.org/10.1002/ecs2.1594

Ruel JJ, Ayres MP (1996) Variation in temperature responses among populations of Betula papyrifera. Silva Fenn 30:145-158

Sade N, Gebremedhin A, Moshelion M (2012) Risk-taking plants: anisohydric behavior as a stress-resistance trait. Plant Signal Behav 7:767-770. https://doi.org/10.4161/psb.20505

Safford LO, Bjorkbom JC, Zasada JC (1990) Betula papyrifera. In: Burns RM, Honkala BH (eds) Silvics of North America: volume 2. Hardwoods. US Department of Agriculture, Forest Service, Agriculture Handbook no. 654, Washington, DC, pp 158-171 
Sala A, Woodruff DR, Meinzer FC (2012) Carbon dynamics in trees: Feast or famine? Tree Physiol 32:764-775. https://doi.org/10.1093/treephys/tpr143

Savage M, Mast JN, Feddema JJ (2013) Double whammy: high-severity fire and drought in ponderosa pine forests of the Southwest. Can J For Res 43:570-583. https://doi.org/10.1139/cjfr-2012-0404

Schier GA, Jones JR, Winokur RP (1985) Vegetative regeneration. In: DeByle NV, Winokur RP (eds) Aspen: ecology and management in the western United States. US Department of Agriculture, Forest Service, General technical report RM-119, Fort Collins, CO, pp 29-33

Serra-Diaz JM, Maxwell C, Lucash MS et al (2018) Disequilibrium of fire-prone forests sets the stage for a rapid decline in conifer dominance during the 21st century. Sci Rep 8:6749. https://doi. org/10.1038/s41598-018-24642-2

Shinneman DJ, Baker WL, Rogers PC, Kulakowski D (2013) Fire regimes of quaking aspen in the Mountain West. For Ecol Manag 299(2013):22-34

Sirois L (1993) Impact of fire on Picea mariana and Pinus banksiana seedlings in subarctic lichen woodlands. J Veg Sci 4:795-802

Sirois L (1995) Initial phase of postfire forest regeneration in two lichen woodlands of northern Québec 1. Écoscience 2:177-183

Sirois L (2000) Spatiotemporal variation in black spruce cone and seed crops along a boreal forest- tree line transect. Can J For Res 30:900-909

Sperry JS, Sullivan JEM (1992) Xylem embolism in response to freeze-thaw cycles and water stress in ring-porous, diffuse-porous, and conifer species. Plant Physiol 100:605-613. https://doi. org/10.1109/Agro-Geoinformatics.2012.6311726

Sperry JS, Nichols KL, Sullivan JEM, Eastlack SE (1994) Xylem embolism in ring-porous, diffuseporous, and coniferous trees of northern Utah and interior Alaska. Ecology 75:1736-1752

Splawinski TB, Gauthier S, Fenton NJ et al (2018) The colonization of young fire initiated stands by the crustose lichen Trapeliopsis granulosa and its potential effect on conifer establishment and stand succession. Silva Fenn 52:1-18

Splawinski TB, Greene DF, Michaletz ST et al (2019) Position of cones within cone clusters determines seed survival in black spruce during wildfire. Can J For Res 49:121-127. https://doi.org/10.1139/ cjfr-2018-0209

Stevens-Rumann CS, Morgan P (2019) Tree regeneration following wildfires in the western US: a review. Fire Ecol 15:1-17. https://doi.org/10.1186/s42408-019-0032-1

Stevens-Rumann CS, Kemp KB, Higuera PE et al (2017) Evidence for declining forest resilience to wildfires under climate change. Ecol Lett 21:243-252. https://doi.org/10.1111/ele.12889

Tepley AJ, Thompson JR, Epstein HE, Anderson-Teixeira KJ (2017) Vulnerability to forest loss through altered postfire recovery dynamics in a warming climate in the Klamath Mountains. Glob Chang Biol 23:4117-4132. https://doi.org/10.1111/gcb.13704

Terrier A, Girardin MP, Cantin A et al (2015) Disturbance legacies and paludification mediate the ecological impact of an intensifying wildfire regime in the clay belt boreal forest of eastern North America. J Veg Sci 26:588-602. https://doi.org/10.1111/jvs.12250

Thomas PA, Wein RW (1985) Delayed emergence of four conifer species on postfire seedbeds in eastern Canada. Can J For Res 15:727-729

Thomson AM, Riddell CL, Parker WH (2009) Boreal forest provenance tests used to predict optimal growth and response to climate change: 2. Black spruce. Can J For Res 39:143-153. https://doi. org/10.1139/X08-167

Tjoelker MG, Oleksyn J, Reich PB (1998) Temperature and ontogeny mediate growth response to elevated $\mathrm{CO}^{2}$ in seedlings of five boreal tree species. New Phytol 140:197-210. https://doi.org/10.10 46/j.1469-8137.1998.00272.x

Tweddle JC, Dickie JB, Baskin CC, Baskin JM (2003) Ecological aspects of seed desiccation sensitivity. J Ecol 91:294-304. https://doi.org/10.1046/j.1365-2745.2003.00760.x

Ulery AL, Graham RC (1993) Forest fire effects on soil color and texture. Soil Sci Soc Am J 57:135-140

Urli M, Porté AJ, Cochard H et al (2013) Xylem embolism threshold for catastrophic hydraulic failure in angiosperm trees. Tree Physiol 33:672-683. https://doi.org/10.1093/treephys/tpt030

Van Bogaert R, Gauthier S, Raulier F et al (2015) Exploring forest productivity at an early age after fire: a case study at the northern limit of commercial forests in Quebec. Can J For Res 45:579-593. https://doi.org/10.1139/cjfr-2014-0273

Van Wagner CE (1978) Age-class distribution and the forest cycle. Can J For Res 8:220-227

Viereck L (1983) The effects of fire in black spruce ecosystems of Alaska and northern Canada. In: Wein RW, MacLean DA (eds) The role of fire in northern circumpolar ecosystems. Wiley, New York, pp 201-220 
Viereck LA, Dyrness CT (1979) Ecological effects of the Wickersham dome fire near Fairbanks, Alaska. US Department of Agriculture, Forest Service, General technical report PNW-90

Vitasse Y, Schneider L, Rixen C et al (2018) Increase in the risk of exposure of forest and fruit trees to spring frosts at higher elevations in Switzerland over the last four decades. Agric For Meteorol 248:60-69. https://doi.org/10.1016/j.agrformet.2017.09.005

Volaire F (2018) A unified framework of plant adaptive strategies to drought: crossing scales and disciplines. Glob Chang Biol 24:2929-2938. https://doi.org/10.1111/gcb.14062

Walker XJ, Mack MC, Johnstone JF (2017) Predicting ecosystem resilience to fire from tree ring analysis in black spruce forests. Ecosystems 20:1137-1150. https://doi.org/10.1007/s10021-016-0097-5

Wan X, Landhäusser SM, Zwiazek JJ, Lieffers VJ (1999) Root water flow and growth of aspen (Рориlus tremuloides) at low root temperatures. Tree Physiol 19:879-884. https://doi.org/10.1093/treep hys/19.13.879

Way DA, Sage RF (2008) Elevated growth temperatures reduce the carbon gain of black spruce [Picea mariana (Mill.) B.S.P.]. Glob Chang Biol 14:624-636. https://doi.org/10.1111/j.1365-2486.2007.01513.x

Wilmking M, Juday GP, Barber VA, Zald HSJ (2004) Recent climate warming forces contrasting growth responses of white spruce at treeline in Alaska through temperature thresholds. Glob Chang Biol 10:1724-1736. https://doi.org/10.1111/j.1365-2486.2004.00826.x

Wilton WC (1963) Black spruce seedfall immediately following fire. Can Entomol 39:477-478

Woodward A, Silsbee DG, Schreiner EG, Means JE (1994) Influence of climate on radial growth and cone production in subalpine fir (Abies lasiocarpa) and mountain hemlock (Tsuga mertensiana). Can J For Res 24:1133-1143

Zamorano JG, Hokkanen T, Lehikoinen A (2018) Climate-driven synchrony in seed production of masting deciduous and conifer tree species. J Plant Ecol 11:180-188. https://doi.org/10.1093/jpe/rtw117

Zasada JC, Schier GA (1973) Aspen root suckering in Alaska: effect of clone, collection date, and temperature. Northwest Sci 47:100-104

Zasada JC, Viereck LA (1975) The effect of temperature and stratification on germination in selected members of the Salicaceae in Interior Alaska. Can J For Res 5:333-337

Zasada JC, Sharik TL, Nygren M (1992) The reproductive process in boreal forest trees. In: Shugart HH, Leemans R, Bonan GB (eds) A systems analysis of the global forest. Cambridge University Press, Cambridge, New York, pp 85-125

Zhang S, Dang Q (2007) Interactive effects of soil temperature and $\left[\mathrm{CO}^{2}\right]$ on morphological and biomass traits in seedlings of four boreal tree species. For Sci 53:453-460

Publisher's Note Springer Nature remains neutral with regard to jurisdictional claims in published maps and institutional affiliations.

\section{Affiliations}

\section{Dominique Boucher $^{1}$ (D) . Sylvie Gauthier ${ }^{1,2}$ (D) . Nelson Thiffault ${ }^{3,4}$ (D) . William Marchand ${ }^{1,2}$ (D) Martin Girardin ${ }^{1,2}$ (D) $\cdot$ Morgane Urli $^{4}$ (D)}

1 Natural Resources Canada, Canadian Forest Service, Laurentian Forestry Centre, 1055 du P.E.P.S., Stn. Sainte-Foy, P.O. Box 10380, Québec, QC G1V 4C7, Canada

2 Centre d'étude de la forêt, Université du Québec à Montréal, C.P. 8888, succ. Centre-ville, Montréal, QC H3C 3P8, Canada

3 Natural Resources Canada, Canadian Forest Service, Canadian Wood Fibre Centre, $1055 \mathrm{du}$ P.E.P.S., Stn. Sainte-Foy, P.O. Box 10380, Québec, QC G1V 4C7, Canada

4 Faculté de foresterie, de géographie et de géomatique, Centre d'étude de la forêt, Université Laval, Rue de la Terrasse, Québec, QC, Canada 